\title{
Dergiabant
}

Cilt/Volume: 9, Sayı/Issue: 1

(Mayıs/May 2021)

\section{Tarihten Günümüze Hasidik Yahudiler ve Kendilerine Özgü Dindarlık Anlayışları}

\section{Hasidic Jews from History to Present and Their Specific Understanding of Piety}

\author{
Ömer Faruk Araz \\ Dr. Öğr. Üyesi, Marmara Üniversitesi, İlahiyat Fakültesi, \\ Dinler Tarihi Anabilim Dalı \\ Asst. Prof. Dr., Marmara University, Faculty of Theology, \\ Department of History of Religions \\ Istanbul/Turkey \\ omer.araz@marmara.edu.tr \\ orcid.org/0000-0002-7425-4164
}

\section{Makale Bilgisi $\quad$ Article Information}

Makale Türü: Araştırma Makalesi

Geliş Tarihi: 24 Ocak 2021

Kabul Tarihi: 4 Mart 2021

Yayın Tarihi: 30 Mayıs 2021

Yayın Sezonu: Bahar
Article Type: Research Article

Date Received: 24 January 2021

Date Accepted: 4 March 2021

Date Published: 30 May 2021

Publication Season: Spring

https://doi.org/10.33931/abuifd.867612

(

İntihal/Plagiarism

Bu makale özel bir yazılımla taranmış ve intihal tespit edilmemiştir.

This article has been scanned by a special software and no plagiarism detected.

\section{Atıf/Cite as}

Araz, Ömer Faruk. "Tarihten Günümüze Hasidik Yahudiler ve Kendilerine Özgü Dindarlık Anlayışları". Dergiabant 9/1 (Mayıs 2021), 124-150. https://doi.org/10.33931/abuifd.867612

Copyright $\odot$ Published by Bolu Abant Izzet Baysal University Faculty of Theology, Bolu, 14030 Turkey. All rights reserved. https://dergipark.org.tr/tr/pub/dergiabant 


\title{
Tarihten Günümüze Hasidik Yahudiler ve Kendilerine Özgü Dindarlık Anlayışları
}

\section{Öz}

Hasidizm 18. yüzyılda Doğu Avrupa'da İsrael ben Eliezer tarafından kurulan, mistik yönü ağır basan bir dini harekettir. Günümüzde ABD’nin New York kentinde yoğun olarak yaşayan bu hareketin mensupları, modern yaşamın bütün cazibesine rağmen özellikle teknoloji ve internet kullanımı ile moda endüstrisine karşı mesafeli durușlarıyla kendilerine has yașayıș biçimlerini ve dindarlık anlayıșlarını ısrarla sürdürmeye çalıșmaları ile tüm dünyanın dikkatini çekmektedirler. 18. Yüzyılda bir taraftan Avrupa'da doğan Yahudi aydınlanma hareketi olan Haskala ile tezahür eden reformist düşüncenin Yahudilerin dini hayatlarında Rabbâni Yahudiliğin yüzlerce yıldır uygulanan dindarlık biçimini sarsmaya başlaması, diğer taraftan reformistlerden çok farklı bir şekilde kendine has yeni bir dindarlık anlayışı ortaya çıkmakta ve süratle gelişmekteydi. Zamanla "Hasidizm" olarak isimlendirilecek olan bu hareket, geleneksel Yahudi dini hayatının temel dinamikleri olan Kutsal Kitap ve Talmud çalışmaları yaparak Yahudi dini hukuku "halaha"ların çizdiği çerçeveye bağlı bir yaşam sürmenin ve yüzlerce yıldır uygulanan ritüellerin yerine "saddik" ya da "rebbe" denilen karizmatik bir lider, iman, sevgi, dini coşku, raks, dini hikaye anlatımı gibi kendine has yeni önceliklerin dini hayatın merkezinde yer aldığı bir anlayışı ortaya koymuş; dini ritüellere ve geleneksel dindarlığa yaklaşımı ile söylemleri bağlamında Protestanlığın Hıristiyanlık içerisinde oynadığı temel rolü çağrıştırsa da, Hasidizmin pratik sonuçları itibarıyla modern topluma aykırı bir tipoloji olarak farklı bir dini duruş ortaya çıkmış ve halk tabakaları arasında ciddi destek görmüştür. Biz çalışmamızda Hasidik hareketin ortaya koyduğu yeni uygulamaları izah ederek bunların geleneksel çizgiden ne ölçüde farklı olduğunun mukayesesine yer verdikten sonra modern zamanlarda, modern toplumlar arasında Hasidik Yahudilerin kendilerine has yaşamlarını nasıl sürdürdükleriyle ilgili tespitlerimizi sunmaya çalışacağız.

Anahtar Kelimeler: Dinler Tarihi, Yahudilik, Hasidizm, Rabbani Yahudilik, Dindarlık.

\section{Hasidic Jews from History to Present and Their Specific Understanding of Piety}

\begin{abstract}
Hasidism is a religious movement with a predominant mystical aspect, and was founded in Eastern Europe in the $18^{\text {th }}$ century by Israel ben Eliezer. Nowadays, the members of this movement, who live heavily in New York city of the USA, attract the attention of the world, despite all the charm of modern life, with their efforts to maintain their way of life and their understanding of religiosity, especially with their distant stance against the fashion industry with the use of technology and internet. In the $18^{\text {th }}$ century, the reformist thought manifested with Haskala, The Jewish enlightenment movement, on the one hand, a new understanding of religiosity emerged, on the other, very different from the reformists, and it was developed rapidly and this new religious way of life started to shake the religious understanding of the Rabbinic Judaism in the religious lives of the Jews. This movement, which will eventually be called "Hasidism", has transformed rituals and religious understanding, which have been believed and practiced for hundreds of years. Instead of living a life adhering to the framework driven by the "halakha" by doing Bible and Talmud studies, which are the basic dynamics of traditional Jewish religious life, Hasidism has adopted a new understanding in which its own new priorities are at the center of religious life, such as a charismatic leader called "tsaddik" or "rebbe", faith, love, religious enthusiasm, dance, religious storytelling. Although Hasidism evokes the
\end{abstract}


fundamental role played by Protestantism in Christianity in the context of its approach to rituals and traditional religiosity and its discourses, due to the practical consequences of Hasidism, and different religious stance emerged as a typology contrary to modern society, and it gained support, especially among ordinary people. In this study, we will present our findings about how Hasidic Jews lived their unique lives among modern societies in modern times, after explaining the new practices that the Hasidism has revealed and comparing their differences from the traditional line.

Keywords: History of Religions, Judaism, Hasidism, Rabbinic Judaism, Piety.

\section{Giriş}

Hasidizm kelime olarak "dindar" anlamındaki "hasid" kelimesinden gelir. Samimi dindarlığı, Tanrıyla manevi birlikteliği ve yaratıcısına özel bir bağlılıkla hizmet etmeyi ifade eder. 1 "Hasid" kelimesi Tevrat'ta dindar kişi anlamında kullanıldığı gibi Tanrı'ya yönelik olarak da kullanılır. Mezmurlar 145:17 ve 149:5'teki kullanımlar buna örnektir. ${ }^{2}$ Kelime aynı anlamda rabbâni literatürde, Mişna ve Talmud'da da sıklıkla kullanılır. ${ }^{3}$

$\mathrm{Bu}$ hareketin öncesinde tarihte aynı isimde başka bazı hareketler olmuştur. M.Ö. 2. yy.'da IV. Antiochus Epiphanes'in Yahudiliği helenleştirme çabasına karşı çıkan bir grup ile 12-13. yy.'larda günümüz Almanya'sında ortaya çıkan Aşkenazi Hasidizm'i bu gruplara örnektir. 18. yy.'da ortaya çıkan hasidik hareket, tarihteki bu örneklerden ayırmak için "BeŞT'çi Hasidizm" veya "BeŞT Hasidizmi" olarak da isimlendirilir. ${ }^{4} \mathrm{Bu}$ hareketin ortaya çlkışı öncesinde bölgede "Hasidim" olarak isimlendirilen asketik yönü ağır basan, Kabalacı özellikler sergileyen ve Rabbani Yahudilerin mesafeli durduğu küçük çaplı mistik grupların varlığı bilinmektedir. ${ }^{5}$

Çalışmamızda incelediğimiz Hasidizm, farklı ülkelerde değişik sosyal zeminlerde yüzlerce yıldır oluşmuş, sosyal, teolojik, ideolojik vb. alanlarda birbirinden bazı farkları olan, bazen birbirleri ile ciddi rekabet ve mücadeleye girişmiş ve yönetim tarzı olarak farklı liderlik anlayışı sergileyen, kurucusu BeŞT’in

Herman Rosenthal - S. M. Dubnow, "Hasidim, Hasidism”, The Jewish Encyclopaedia (New York and London: Funk and Wagnalls Company, 1904), 6/251.

2 Kitab-ı Mukaddes (İstanbul: Kitabı Mukaddes Şirketi, 1997) Mez. 145:17: Tanrı bütün davranışlarında adil, yaptığı bütün işlerinde sevecendir. 149:5: Bu onurla mutlu olsun sadık kulları, sevinç ezgileri okusunlar yataklarında.

$3 \quad$ Harry M. Rabinowicz, The World of Hasidism (London: Vallentine, Mitchel, 1970), 184.

4 Shmuel Ettinger, "The Hasidic Movement-Reality and Ideals", Essential Papers on Hasidism, ed. Gershon David Hundert (New York and London: New York Univ. Press, 1991), 227; Joseph Dan, "Hasidism", Encyclopaedia of Religion (USA: Macmillan Reference USA, 2005), 6/3785. E. Monet, "Hasideans, Hasidism", Encyclopaedia of Religion and Ethics, ed. James Hasting (Edinburg: T.\&T. Clark, 1919), 6/526. Eva Van Loenen, "A Fresh Perspective on the History of Hasidic Judaism", eSharp, 20 (Spring 2013): 3.

5 Avraham Rubinstein, "Hasidism", Encyclopaedia Judaica (USA: Macmillan Reference USA, 2007), 8/393; Rabinowicz, The World of Hasidism, 184; Moshe Rosman, "The Rise of Hasidism", The Cambridge History of Judaism: The Early Modern World, 1500-1815, ed. Jonathan Karp - Adam Sutcliffe (Cambridge: The Cambridge Univ. Press, 2018), 7/628-631. Sharon Flatto, "Hasidim and Mitnaggedim: Not a World Apart", The Journal of Jewish Thought and Philosophy 12/2 (August 2003): 99-121. 
ölümünden sonra yirmi yıl içinde yayılarak pek çok grup ve alt grubu ifade eden çatı bir isim haline gelmiştir. ${ }^{6}$

\section{Hasidik Yahudiliğin Ortaya Çıkışı ve Gelişimi}

\subsection{Hasidizm'in Ortaya Çıkışı}

Hasidizm 18. yy.'ın başlarından itibaren doğu Avrupa'da ortaya çıkmıştır. Bu dönemde bölgedeki Yahudilerin durumu incelendiğinde, güneybatı Ukrayna ile Polonya'daki Yahudi toplulukların genellikle köylerde ve entelektüel merkezlerden uzaklarda yaşadıkları görülür. Buralarda mistik doktrin ve eğilimler hâkimdi. Kuzey batıdaki Litvanya ve Beyaz Rusya bölgelerinde ise rabbâni geleneğin hakimiyetinde Yahudi toplulukların büyük oranda şehirlerde yaşadıkları görülmekteydi. Ayrıca güney bölgelerdeki Yahudiler, "Kosak Ayaklanması" da denilen "Chmielnicki" liderliğindeki isyanda (1648-1660) hedef alındığından dolayı ekonomik olarak kuzeye nispeten kötü durumdaydı. ${ }^{7}$

Hasidizm'in ortaya çıktığı dönemde Yahudilerin dini lideri olan "Rabbi”ler Tora çalışmakla ve toplumun şeriat kurallarını tatbikini takiple yetiniyorlardı. Çoğunlukla zenginler ve devlet yöneticileriyle ilgileniyorlar, sıradan halkı ihmal ediyorlardı. İbadetlerde ve din anlayışında şekilcilik öne çıkıyordu. BeŞT ve müritleri ise rabbilerin aksine toplumda günahkâr addedilen ve dışlanan insanlarla ilgileniyordu. Kendi aralarında dinin coşkulu bir şekilde mistik tecrübeye dayanan tatbiki söz konusuydu. Bu yönüyle hasidik hareket, bölgede siyasi, ekonomik, sosyal ve dini krizlerin yaşandığı bir dönemde ortaya çıkan, mensupları arasında alt tabakadan insanların yoğun olarak bulunduğu, halaha kurallarının biçimsel uygulanması yerine onların ruhani yönüne vurgu yaptığından duygusal boyutu ağır basan, mevcut şekilci din anlayışına karşı mistik bir tepki idi. ${ }^{8}$

Genel olarak Hasidizm'in dönemin sosyal, ekonomik, siyasi ve dini şartlarına karşı reaksiyoner bir hareket olarak ortaya çıtığı kabul edilmekle birlikte bu hareketin Orta Çağ Felsefesi ile 13. yy. Kabala Literatürü ve MaHaRaL'ın (1525-1609) mistik yazıları gibi o dönemdeki Yahudi dini metinlerin yeni bir düzenlemesi ve yorumlanması, daha önceki farklı mistik yaklaşımların bir sentezi olduğu iddiaları da mevcuttur. ${ }^{9}$ Ancak mistik bir hareket olması sebebiyle hasidik düşünce ile yukarıda

David Assaf, "Hasidism, Historical Overview", The Yivo Encyclopedia of Jews in Eastern Europe (New Haven (Conn.): Yale Univ. Press, 2008), 1/659; David Biale vd., Hasidism: A New History (USA: New Jersey: Princeton Univ. Press, 2018), 6. Rabinowicz, The World of Hasidism, 183. Rosenthal - Dubnow, "Hasidism", 6/252; Miriam B. Caravella, The Mystic Heart of Judaism (New Delhi: Science of the Soul Research Centre, 2011), 401; John Klier, "Pogroms", The Yivo Encyclopedia of Jews in Eastern Europe (Yivo Institute for Jewish Research), (Erișim 02 Mart 2020), https://yivoencyclopedia.org/article.aspx/Pogroms; Rubinstein, "Hasidism", 8/393. Caravella, The Mystic Heart of Jud., 402; Rosenthal - Dubnow, "Hasidism", 6/252; Kaufmann Kohler - Louis Ginzberg, "Ba'al Shem Tob, Israel ben Eliezer", The Jewish Encyclopaedia (USA: Funk and Wagnalls Company, 1903), 2/385; Biale vd., Hasidism, 3-4; Van Loenen, "A Fresh Perspective", 4.

9 Moshe Idel, Hasidism Between Ecstacy and Magic (New York: State Univ. of New York Press, 1995), 9-18; Rosenthal - Dubnow, "Hasidism", 6/252; Biale vd., Hasidism, 6; Farklı Hasidizm tanımları 
zikredilen önceki Yahudi mistik hareketler arasında bazı benzerlikler söz konusu olsa da Hasidizm'i o hareketlerin devamı gibi görmek kolaylıkla mümkün değildir. ${ }^{10}$

Hasidik hareketin ortaya çıkması ve yayılmasında Sabatay Sevi ve Jacob Frank hareketinin bazı etkileri söz konusudur. Sabatay Sevi'nin takipçileri ile birlikte Müslüman olması, Jacob Frank ve takipçilerinin de Hıristiyanlığa geçmeleri, toplum içerisinde rabbilerin kontrolündeki Yahudilik yorumundan memnuniyetsizliklerin ve arayışların olduğunu göstermektedir. Ayrıca Talmud karşıtlığının ve kabalacıllı̆ın mistik ve batınî yorumunun bu hareketlerde ortak olması, onların rabbâni otoriteyi kabul etmediklerinin ve aralarında açık ya da gizli bir etki(leşim)in olabileceğine işarettir. ${ }^{11}$ Bunun yanı sıra hasidik hareketin bir taraftan Sabatayistler ve Frankistlerle dinin kabalacı mistik yorumunda benzeşirken diğer taraftan onlardan farklılaşarak kabala metafiziği yerine kabala mistisizmini pratize etmeleri ve kendilerini Yahudilik dairesi içerisinde konumlandırmaları, onları mevcut durumdan, yani rabbilerin geleneksel Yahudilik anlayışından memnun olmayan ancak dinlerinden de ayrılmak istemeyen kişiler için bir alternatif haline getirmiştir. ${ }^{12}$ Sonuçta yeni bir Yahudilik yorumunun geliştiğini ve toplumda karşllık bulduğunu gören rabbiler, kendi kontrollerindeki geleneksel Yahudilik anlayışını koruma sâikiyle ilk hasidik liderlere karşı sert bir yaklaşım sergilemişler, uzunca bir süre bu hareket ile çeşitli mecralarda mücadele etmişlerdir.

\subsection{Hasidizm'in İlk Liderleri ve Gelișim Süreci}

Hasidizm'in kurucusu olarak Israel ben Eliezer, (Baal Șem Tov, BeŞT) (17001760) kabul edilir. Kutsal isimleri kullanarak sihir, büyü vb. unsurlarda mahir olan, bunlarla ruhani alemle irtibat kurarak bazı hastalıkları tedavi eden bir tür şaman olan kimselere verilen bir unvan olan "Baal Șem", kelime olarak "isim üstadı" anlamına gelmektedir. Israel ben Eliezer yaklaşık on yıl boyunca ruhsal hastaları tedavi eden, cin çıkaran, muska yazan, şifacılık yaparak ünlendikten sonra lakabına "Tov" (iyi) kelimesi de eklenerek Baal Şem Tov olarak anılmaya başlar. Dini eğitimi olmadığından kendi yeni dini söylem ve anlatılarında hikayeler ve özlü halk deyişlerini kullanmıştır. Şöhretinin artmasıyla gezerek çalışmak yerine Miedzyboz'a

için bk. Ebru Metli, Hasidizm'in Yahudi ve Öteki Anlayışı (Yüksek Lisans Tezi, Ankara Üniversitesi, 2006), 2-3.

10 Ayrıntılı bilgi için bk. Mordecai L. Wilensky, "Hasidic-Mitnaggedic Polemics in the Jewish Communities of Eastern Europe: The Hostile Phase", Essential Papers on Hasidism, ed. Hundert, Gershon David (New York and London: New York Univ. Press, 1991), 119-121; Kürşat Demirci, “Doğu Avrupa Yahudiliği: Hasidizm”, Din Eğitimi Araştırmaları Dergisi, 16 (2005): 119, 121. Bernard Martin, A History of Judaism : Europe and the New World (New York: Basic Books, 1974), 2: 170; Martin Buber, The Origin and Meaning of Hasidism., trc. Maurice Friedman (New Jersey: Humanities Press, 1993), 29; Dan, "Hasidism", 6/3786; R. Aryeh Leifert, "The Role of Messianism in the Development of Hasidism", Milin Havivin, 2 (2006): 121-127; Kohler - Ginzberg, "Baal Shem Tob", 2/384.

12 Kürşat Demirci, Yahudi Mistisizmi veya Kabalacılık (İstanbul: Ayıșığı Kitapları, 2015), 6-7; Kürşat Demirci, "Yahudi Mistisizminin Temel Özellikleri ve Gelişimi", Insan ve Toplum Bilimleri Araștırmaları Dergisi 4 (2012): 16-17; Metli, Hasidizm'in Yahudi ve Öteki Anlayışı, 3-5. 
yerleşmiş; Tanrı'nın kendisini özel bir görevle görevlendirerek doktrinini yaymasını istediğini; gördüğü vizyonların görevini kendisine gösterdiğini ileri sürmüştür. ${ }^{13}$

BeŞT'in yeni bir hareket kurarak eski dini yapıyı yıkmayı amaçlamadığını ifade edebiliriz. 0 ve müritleri kendilerini geleneksel Yahudilikten ayrılmadan mistik bazı uygulamalar yapıyor, bunu dünyadan el etek çekmeden yapmasıyla kendisinden önceki mistik hareketlerden ayrışıyorlardı. Onun bir hareket kurucusu olarak görülmesi birkaç kuşak sonradır. ${ }^{14}$

Vefat ettiğinde BeŞT'ten geriye kalan tek doküman 1750'li yıllarda kayınbiraderi R. Gershon'a yazdı̆̆ı mektuptur. Bu mektupta ruhunun ilahi âleme yükselerek Mesih ile karşılaştığında Mesih'in Tannaim alimleri ve Tsadiklerle Tora çalışır vaziyette olduğunu; Ona ne zaman dünyaya geleceğini sorduğunda Mesih, 'sizin hareketiniz dünyaya yayıldığı zaman' dediğini aktarmaktadır. ${ }^{15}$

BeŞT zamanında hareket bir vaaz halkası biçimindeyken onun vefatı sonrası hareketin lideri olan Dov Ber (1704-1772) ya da Mezritsh'li Maggid (vaiz) Hasidizm'in teolojisinin oluşmasına büyük katkı sağlamış ve hareketi büyüterek bir organizasyon haline dönüşmesine öncü olmuştur. Onun döneminde eğitimli kişiler de harekete dahil olmaya başlamıştır. ${ }^{16}$ Maggid sonrasında hareket liderlik yapan Jacob Joseph ise ilk yazılı kaynakları ortaya çıkarmıştır. ${ }^{17}$ 1780'de Toledot Yaakov Yosef basılmıştır. Bunu 1781'de basılan Dov Ber'in vaazları olan Magid de va Rav le-Yaakov, Lizhensk'li Elimelek'in 1788 tarihli Noam Elimelekh isimli eseri ile Şneur Zalman'ın Tanya adlı kitabı izlemiştir. 1815 yılında ise Hasidik cemaatin en önemli eserlerinden birisi olan, BeŞT ve müritleriyle ilgili hikayelerin yer aldığı Şivhe ha-Beşt (BeŞT'in Övgüsü) yayınlanırken bunu Bratslav'lı Nahman'ın talebelerine anlattığı 13 hikâyenin yer aldığı Sipure Maasiyot isimli çalışma izler. BeŞT’in herhangi bir eser yazmaması ve onunla ilgili ilk yazılanların vefatından çok sonra müritleri tarafından yarı gerçek yarı efsanelerle süslenmiş olarak kaleme alınması ilk dönem kilise teşkilatı ile (Hz.) İsa'nın ilişkisine benzetilebilir. 18

Dov Ber'in 1772 yılında ölümü sonrasında belli ekoller ortaya çıkmaya başlar. Onun talebeleri olan Lizhensk'li Elimelekh, Barditshev'li Levi Yitshak, Kalisk'li Avraham, Vitebsk'li Menahem Mendel ve Liady'li Shneur Zalman bunlara örnektir. Bunlar Doğu Avrupa'da farklı bölgelerinde, Maggid'in görüşlerine sadık kalmakla

Kohler - Ginzberg, "Baal Shem Tob”, 2/383-384, 386; Rosenthal - Dubnow, "Hasidism”, 6/252; Martin, A History of Jud., 2/172; Biale vd., Hasidism, 3; Yohanan Petrovsky-Shtern, "Ba'ale Shem", The Yivo Encyclopedia of Jews in Eastern Europe (Yivo Institute for Jewish Research), (Erişim 02 Şubat 2020), https://yivoencyclopedia.org/article.aspx/Baale_Shem; Rosman, "The Rise of Hasidism", 7/631-632. Biale vd., Hasidism, 7; Rabinowicz, The World of Hasidism, 183.

Ettinger, "The Hasidic Movement", 228; Caravella, The Mystic Heart of Jud., 414; Kohler - Ginzberg, "Baal Shem Tob", 2/384; Gershom Scholem, The Messianic Idea in Judaism (New York: Schocken Books, 1971), 182.

16 Metli, Hasidizm'in Yahudi ve Öteki Anlayıșı, 9-10.

17 Caravella, The Mystic Heart of Jud., 404-414; Rosman, "The Rise of Hasidism", 7/639; Ayrica bk. Mor Altshuler, The Messianic Secret of Hasidism (Leiden\&Boston: Brill, 2006), 4-5. Biale vd., Hasidism, 8; Dan, "Hasidism", 6/3787; Assaf, "Historical Overview", 1/661-664. 
birlikte organizasyon yapısı veya bazı doktrin farklılıkları ile kendi gruplarını oluşturmuşlardır. Yaklaşık 1740'lı yıllardan başlayarak Maggid'in talebelerinin tarih sahnesinden çekildiği 1815 yılına kadarki süreç "Erken Dönem Hasidizm" olarak isimlendirilir. ${ }^{19}$

Bir sonraki aşamada Hasidik aile hanedanlıkları ortaya çıkmıştır. 19. yy.'da sistemli hale gelen bu gruplar genelde bulundukları kasabanın adıyla anılıyor, tsadik ismi verilen liderin ölümü sonrası oğlu, yoksa damadı ya da önemli müritlerinden birisi yeni lider oluyor; bazen diğer oğullarından kendi gruplarını kuranlar çlkabiliyordu. ${ }^{20}$

\subsection{Hasidizm'in Geleneksel Yahudilikle Mücadelesi}

Hasidizm'in doğuşu ve yayılması sürecinde Yahudiliğin geleneksel çizgisini temsil eden ve cemaatin yönetimini elinde tutan rabbiler ile ciddi tartışmalar ve gerginlikler ortaya çıkmıştır. "Mitnagedim” olarak anılacak Hasidizm karşıtı cephenin Hasidiklere yönelik temel suçlamalar ilk olarak Zemir Aritsim ve Harevot Surim isimli 1772 tarihinde yayımlanan risalede şöyle sıralandı: Duada ve ibadette hâkim Aşkenaz geleneği reddetmek, kendi ayrı ibadethane ve cemaatlerini kurmak, dini kesim (şehita) kurallarını değiştirmek, Tora'yı ve Tora alimlerini aşağılamak, Sabataycılık şüphesi, devamlı kutlama yapmak. ${ }^{21}$

Hasidizm- Mitnagedim çatışması 1772, 1781 ve 1796 tarihlerinde yaşanan bazı gelişmelere bağlı olarak üç ayrı dönemde alevlenmiş, Hasidizm için herem fetvaları yayınlanmıştır. 1781 yılındaki fetvada şöyle denilmektedir: "Onlar eş ve çocuklarıyla cemaatimizden derhal çıkarılmalıdır... Onlara tek gecelik konaklama imkânı bile verilmemeli, kestikleri yenmemeli, onlarla iş/ticaret yapılmamalı, evlenilmemeli, cenazelerine katılmamalı..."22

Bu mücadele zamanla Yahudi cemaatinin iç meselesi olmaktan çlkarak her iki taraf tarafından çeşitli resmi otoritelere intikal ettirilmiştir. Mitnagedim, Yahudiliğin sinagog dışında ibadeti yasakladığı, Sinagogda ibadete katılmayanların hükümetin gönderdiği ve orada ilan edilen devlet emirlerini duyamadıkları ve ayrılanların

19 Assaf, "Historical Overview", 1/659-663; Rosenthal - Dubnow, "Hasidism”, 6/253; Joseph Berger, The Pious Ones: The World of Hasidim and Their Battles with America (New York: Harper Perennial, 2014), 82-85; Biale vd., Hasidism, 4; Bu cemaatlerin tarihsel gelişimi için bk. Rabinowicz, The World of Hasidism, 129-138.

20 Biale vd., Hasidism, 4-8; Dan, "Hasidism", 6/3787; Tartışmalar için bk. Assaf, "Historical Overview", 1/668.

21 Rosman, "The Rise of Hasidism”, 7/638; Rachel Elior, The Mystical Origins of Hasidism (Oxford: The Littman Library of Jewish Civilization, 2008), 95-96; Wilensky, "Hasidic-Mitnaggedic Polemics", 247-253.

22 Wilensky, "Hasidic-Mitnaggedic Polemics", 245; Rubinstein, "Hasidism”, 8/394, 396; Vilna'da Hasidizm karşıtlı̆̆ının öncüsü olan Vilna Gaon'un hayatı hakkında ayrıntılı bilgi için bk. Louis Ginzberg, Students Scholars and Saints (New York: Meridian Books and Jewish Pub. Society, 1958), 125-144; Rosenthal - Dubnow, "Hasidism", 6/254. 
Sinagogda toplanarak hükümete verilen vergiyi de vermediklerinden bu durumun vergi gelirini düşürdüğünü ileri sürüyordu. ${ }^{23}$

Hasidik Yahudiliğe ilk karşı çıkanlar geleneksel din eğitimi almış Talmud âlimleri rabbiler olduğu ifade edilse de muhalifler arasında "Maggid" ismi verilen gezici vâizler de bulunuyordu. R. Israel Loebel, R. Jacob Israel ve Makov'lu R. David bunlar arasında sayılabilir. Ancak başka muhaliflerden de söz etmek mümkündür. Altona'lı Jacob Emden (1697-1776), Fuerth'lı Joseph Steinhardt (1720-1776), Prag'lı Ezekiel Landau (1713-1793) bu isimlerdendir. ${ }^{24}$

\subsection{Hasidizm'in Dünyaya Dağılması}

19. yy. Hasidizm'in Doğu Avrupa'nın her köşesine yayıldığı çağdır. 20. yy.'ın ortalarında Doğu Avrupa'da hanedanlık biçiminde yönetilen yüzden fazla hasidik cemaat bulunuyordu. Bu dönemde bölgedeki Yahudi nüfusun yaklaşık yarısı Hasidik öğretiyi kabul etmişti. Bu yüzyılda ortaya çıkan Yahudi Aydınlanma Hareketi Haskala'nın ${ }^{25}$ oluşturduğu tehdit sebebiyle Ortodoks Yahudilik ile Hasidizm arasındaki gerginlik giderek azaldı. Çünkü Haskala hareketi, Yahudi toplumunda dini ya da ekonomik bir hegemonya oluşturmaktan ziyade, Yahudi toplumunun dini ve kültürel kimliğini oluşturmada hangi ruhun etkili olacağına yönelik bir "muhafazakarlık - yenilikçilik" mücadelesi biçiminde algılanıyordu. Muhafazakâr cepheyi Rabbâni Yahudilik ile Hasidikler oluştururken yenilikçi tarafta ise Haskala hareketi ve reform yanlıları yer alıyordu. ${ }^{26}$

Hasidizm'in Avrupa dışına -çoğunlukla Amerika kıtasına- dağılmasında, yaşanan siyasi ve sosyal hadiselere bağlı gerçekleşen göçler önemli rol oynamıştır. 19. yy.'ın sonlarında Avrupa ve Rusya'daki karışıklıklar, 1. Dünya Savaşı ${ }^{27}$ ve Bolşevik İhtilali gibi büyük çaptaki hadiseler hasidik grupların yaşayacakları yeni yerler aramalarına neden olmuştur. Ayrıca Yahudi toplumunda başlamış olan sekülerleşme eğilimi Hasidik cemaati çok etkiledi. Sekülerleşme sadece sosyalizm ve siyonizmden beslenmiyor, Haskala hareketinin çabalarıyla artan okullaşma ile birlikte eğitim ve kültür düzeyinin yükselmesi, çöken ştetl (getto) yaşamına paralel olarak ekonomik düzenin değişmesi, endüstrileşme ve şehirleşmenin ortaya çıkardığı işçi hareketi de bu sürece katkı sağlıyordu. Tüm yaşananların etkisi altında Doğu Avrupa'dan,

23 Wilensky, "Hasidic-Mitnaggedic Polemics", 244; Rubinstein, "Hasidism", 8/396; Marcin Wodzinski, Hasidism and Politics: The Kingdom of Poland,1815-1864 (Oxford: The Littman Library of Jewish Civilization, 2013), 47-54, 64; Rosenthal - Dubnow, "Hasidism", 6/253. 24 Ettinger, "The Hasidic Movement", 230; Flatto, "Hasidim and Mitnaggedim", 100; Hasidizm dini Jechiel Meir Halevy, Menahem Mendel, Lublin'li Zadok Kohen gibi tsadikler kendi devirlerinin önemli Talmud rabbileri arasındaydı. Bilgi için bk. Rabinowicz, The World of Hasidism, 186. Haskala ile ilgili ayrıntılı bilgi için bk. Ali Osman Kurt, "Yahudi Aydınlanma Hareketi: Haskala", Milel ve Nihal 7/1 (2010): 33-57.

26 Rabinowicz, The World of Hasidism, 120; Assaf, "Historical Overview", 1/659-661; Caravella, The Mystic Heart of Jud., 439; Stephen Sharot, "Hasidism in Modern Society", Essential Papers on Hasidism (New York and London: New York Univ. Press, 1991), 511.

27 1. Dünya Savașı'nın Hasidizm üzerinde etkisiyle ilgili değerlendirmeler için bk. Marcin Wodzinski - Jarek Garlinsky, "War and Religion; or, How the First World War Changed Hasidism”, The Jewish Quarterly Review 106/3 (Summer 2016): 287-310. 
İngiltere başta olmak üzere, kıtanın batısına ve Amerika'ya kitlesel göç hareketleri başladı. 1890'a kadar Rusya'dan 135.000 Yahudi ABD’ye göçtü. 1. Dünya Savaşı'na kadar yılda ortalama 30.000 Yahudi Rusya'dan ABD'ye göçmeye devam etti. Toplamda bu dönemde Doğu Avrupa'dan göçen Yahudi sayısı iki milyona ulaştı. Bu süreçte hem göçenlerde hem kalanlarda kendini ve değerlerini koruma ve savunma iç güdüsü ile geleneksel değerlere karşı daha tutucu, hatta radikal eğilimler baş gösterdi. 0 tarihlere kadar genellikle Mitnagedim ile ilişkilendirilen "yeşiva" isimli dini eğitim kurumları hasidik gruplar tarafından kurulmaya başlandı. Klasik Tora çalışmalarının yapıldığı yeşivaların açılması aslında geleneksel değerlere bir dönüş ve sekülerizasyona bir cevap verme çabası idi. ${ }^{28}$

2. Dünya Savaşı süresince Holokost'tan çok az sayıda Hasidik Yahudi kurtularak ABD ve İsrail'e kaçtılar. Genelde küçük kasabalarda oluşmuş olan Hasidik cemaatler bu süreçte büyük şehirlere göçmeye ve farklı şehirlere dağılmaya başlaması hareketin daha geniş kitlelere duyurulmasını sağladı. Yeni yurtlarında hiçbir ayırımcılığa ve antisemitik uygulamaya maruz kalmamakla birlikte bir taraftan sayıları kısa süre içerisinde çok azaldı, diğer taraftan açık toplum yapısı içerisinde hâkim kültürün etkisi altında asimile olma tehlikesi ile yüz yüze kaldılar. Bu sebeple kendilerini koruma içgüdüleriyle hareket ederek git gide içlerine kapandılar. ${ }^{29}$ İsrail devletinin kurulması sonrasında buradaki Hasidik gruplar genellikle Siyonizm karşıtı tutum takınmakla birlikte süreç içerisinde -bir kısmı- bu tutumlarından vazgeçtiler. ${ }^{30}$

\section{Geleneksel Yahudi Dindarlığının Temel Unsurları}

Genel olarak dindarlık kişinin hayatında dini değer ve prensiplere uygun yaşaması anlamına gelir. Yahudilikte dindarlık çeşitli inanç ve uygulamaları kapsamaktadır ve "semaya duyulan saygı, haşyet anlamına gelen "yir'at shamayim" kavramıyla ifade edilmektedir. Dindarlığın içe ve dışa dönük tarafları vardır. Dindar bir Yahudinin şeriat kuralları olan halahalara uygun amel ederek Tanrının rızasına uygun yaşamaya çaba göstermesi konunun dışa dönük tarafını, Tanrının her daim huzurunda bulunduğunu kalbinde hissetmesi de içe dönük tarafını anlatmaktadır. ${ }^{31}$

M.S. 70 yılında 2. Mabet'in yıkılması ve 135 yılında Bar Kohba İsyanı sonrasında sürgüne gönderilen Yahudiler yaklaşık olarak iki bin yıl boyunca "diaspora"da yaşamışlar; bulundukları ülkelerde kendi "getto"larında, dış dünya ve diğer inanç ve toplumlarla olabildiğince az temas kurarak yaşamlarını sürdürmüşlerdir. Bu yaşam biçimi onların ilk defa karşılaştığı bir vaziyet değil, Babil

28 Sharot, "Has. in Modern Society", 512-513; Rubinstein, "Hasidism", 8/397; Van Loenen, "A Fresh Perspective", 17; Biale vd., Hasidism, 9; Rabinowicz, The World of Hasidism, 157.

29 Sharot, "Has. in Modern Society", 512-513; Rubinstein, "Hasidism", 8/397; Van Loenen, "A Fresh Perspective", 17.

30 Biale vd., Hasidism, 10; Lloyd P. Gartner, "Hasidism, United States ('Hasidism' içinde)", Encyclopaedia Judaica (USA: Macmillan Reference USA, 2007), 8/397.

31 Arthur Green, "Piety", The Yivo Encyclopedia of Jews in Eastern Europe (Yivo Institute for Jewish Research), (Erişim 03 Şubat 2020), https://yivoencyclopedia.org/article.aspx/Piety; Tzvee Zahavy, "Jewish Piety", The Blackwell Companion to Judaism, ed. Jacob Neusner - Alan J. AveryPeck (Oxford: Blackwell Publishing, 2000), 181. 
sürgününde de tecrübe ettikleri bir durumdu. Bu bağlamda kendi cemaat idarelerinin genellikle dini ve sosyal yaşamlarını tanzim ettiğini ifade edebiliriz. Mevcut olduğu dönemde Yahudi dini hayatının merkezinde yer alan Mabed'in ortadan kalkması ile Yahudilik yeniden düzenlenmiş, Mabed'e bağlı icra edilen kurban ve hac gibi ibadetler artık yapılamaz hale gelince Mabet yerine Yahudi Kutsal Kitabı ikame ediliştir. 2. yy.'da yaşamış olan R. Meir'e göre kişinin kutsal metinlerde Tanrıyı takdis eden cümleleri okumasının pek çok dini uygulamayı icra etmekten daha makbul olduğu görüşünü ifade etmesi bu yaklaşımı yansıtmaktadır. Haskala ile başlayan sürece kadar Yahudi toplumunda yeni dini sisteme yönelik önemli bir muhalefet görülmemiş; "rav" ya da "rabbi" denilen din adamları halahaların uygulanması ile ilgili tüm süreci kontrol altında tutmuşlar; 613 dini emir ve yasağın (mitsva, çoğulu mitsvot) uygulanması ile Yahudi inançlarını tasdik etmesi her Yahudi'den beklenen davranışlar olmuştur. Aslında bu emir ve yasaklar kişinin evde, ibadette, ilişkilerinde ve işlerinde, günlük yaşamının her anını kapsadığından dolayı bunların icrası ile kişiler şeklî olarak dini tatbik etmiş olmaktaydılar. Normal insanlardan beklenen standart dindarlık anlayışının ötesinde Talmud - dolayısıyla Tora- çalışmak Tanrı korkusunu sağlayan en üstün dindarlık faaliyeti olarak kabul edilmiş; 32 eğitimin kişinin manevi arınmasını sağladığına inanılmış, bu sebeple de Talmud çalışan bilginlerin tüm hayatları bu eğitimi sürdürmekten ibaret hale gelmiştir. Buna bağlı olarak Talmud rabbileri Yahudi toplumunda en dindar kişileri, ideal bir âlim ve yönetici profili olarak kabul görmüşlerdir. Bu anlayışla organize edilen bir dini yaşamın merkezinde sinagog ve yanında bulunan "Bet-Midraş" denilen dini eğitimin yapıldığı okullar yer almıştır. ${ }^{33}$

\section{Farklılıkları}

3. Hasidik Yahudiliğin Temel Unsurları, Geleneksel Yahudilik ile

\subsection{Sosyal Düzenleri}

Hasidik cemaatler tsadik ya da rebbe denilen, cemaat üzerinde mensuplarının kabulüne dayanan dini ve dünyevi otoritesi olan liderlerin etrafında şekillenen bir harekettir. Hasidizm hiçbir aristokratik yapıyı benimsemez. Birbirini sevmeyi, inananların eşitliğini salık verir. Fakirlik ve sefaletin kaynağının gönüllerin bir olmaması olduğunu ifade eder. İsrailoğullarının tek vücut olması gerektiğini, "Kimse kendisini komşusundan daha üstün görmemelidir" ifadesiyle vurgular. Hasidik cemaatte yaş, eğitim ya da sosyal statünün önemi yoktur. Herkes ailenin üyesi olarak görülür, sevinç ve üzüntüler, hatta maddi olanaklar paylaşılır. Devlet görevlilerinin hazırladığı çeşitli raporlarda bu konudaki uygulamaların hasidik cemaat arasında sağlıklı yürüdüğü görülmektedir. Ayrıca ebedi kurtuluş, sürgünün bitmesi ve Mesih'in gelişinin Yahudilerin birbirini sevmesi, birlik olması ile gerçekleşeceği inancı vardır.

Ali Osman Kurt, Fundamentalist Yahudiler (Ankara: Eskiyeni Yayınları, 2016), 191-192.

Zahavy, "Jewish Piety", 181; Yahudilerin temel dini eğitim kurumları ile ilgili bilgi için bk. Nuh Arslantaş, "Abbasiler Döneminde Yahudilerin Temel Eğitim Kurumları: Bet ha-Seferler ve Beytülmidraslar", Belleten LXXVIII/282 (Ağustos 2014): 435-474. 
Bu hususu vurgulamak için şu örnek verilir: "Tora 600000 harften oluşmaktadır. Mısır sürgününden çıkanların sayısı da aynıdır. Bu durum, sürgünden çıkan her Yahudinin Tora'da bir kökeni, bir harfinin olduğunu, Yahudi toplumunun birliğinin Tora'nın bütünlüğünü temsil ettiğini gösterir."34

Hasidik cemaatler zamanla müesseseleşmiş ve kendilerine has kurumlara sahip olmuşlardır. Örneğin sinagog'un yerine "știbleh" adı verilen dua evlerini ikame etmiş; Rebbe'lerin bulunduğu "hoyf" ismi verilen külliyeler oluşturulmuş; buralarda onlarla ziyaretçiler arasındaki ilişkileri yöneten "gabbay" denilen aracılar görev almıştır. Bunlar ziyaretçilerin getirdiği "kvittel" denilen, rebbe'den çeşitli isteklerin yer aldığı notları alarak rebbe'ye takdim ederdi. Notlarla birlikte "pidyon" denilen ve miktarı not sahibinin ekonomik durumuna göre ayarlanan ücretler de kabul edilirdi. ${ }^{35}$

\subsection{Tsadik / Rebbe Anlayışı}

"Tsadik" kelimesi "doğru, âdil" anlamındaki "tsedek" kökünden türetilmiştir. "Dürüst kişi" anlamına gelmektedir. "Rebbe" ise bu kelimenin Yiddiş dilindeki ${ }^{36}$ karşılığıdır. "Tsadik" kavramı Tevrat'ta Yaratılış 6:9'da Hz. Nuh için kullanılmakta; Habbakuk 2:4'te doğru kişiyle ilgili anlatımda yer almaktadır. Talmud'da da kelimenin kullanımları mevcuttur. ${ }^{37}$

BeŞT hayatı boyunca kendisinin tsadik olduğunu söylememiştir. Tsadik doktrini ilk olarak Dov Ber'in oğlu Abraham Angel (1741-1776) tarafından formüle edildiği ve babasının talebeleri Lyzhansk'lı Elimelekh ile Lublin'li Jacob Isaac gibi tsadikler tarafından geliștirildiği ifade edilir. Buna göre "tsadik", üstat, danışman, hasid'in kendisine günahlarını itiraf ettiği dini rehber anlamlarını ihtiva eden, hem bu dünyada hem de gelecek dünyada kendisine sadık kişiler için manevi görevler üstlenen yeni bir lider tipi olarak ortaya çıkar. Tsadikler müritleriyle Tanrı arasında aracılık yaparak onların Tanrı'yla mistik birlikteliklerini sağlamaya yardımcı olur. Rabbi'ler gibi cemaat tarafından seçilerek görevini maaş karşılığında yapması söz konusu değildir. Irsî olarak (Kohenler gibi) Yahudi toplumunda bir görevi/sorumluluğu yoktur. Kaynaklarda BeŞT'in talebelerinden Zolochev'li R. Yehiel Mikhel'den ilk tsadik olarak bahsedilir. ${ }^{38}$

34 Martin, A History of Jud., 2/180; Raphael Mahler, "Hasidism and the Jewish Enlightenment", Essential Papers on Hasidism (New York and London: New York Univ. Press, 1991), 419-420, 443444; Rabinowicz, The World of Hasidism, 183.

35 Rabinowicz, The World of Hasidism, 187-188; Rubinstein, "Hasidism”, 8/399.

36 Yiddiş dili Orta ve Doğu Avrupa'da yaşayan Aşkenaz Yahudilerin kullandığı, çoğunlukla Almanca kelimelerin İbrani alfabesiyle yazılması biçiminde gözüken, Almanca, İbranice ve Aramicenin bir tür senteziyle oluşmuş bir dildir. Kökeniyle ilgili farklı görüşler olsa da genellikle 10-11. yüzyıllarda ortaya çıtığı kabul edilir. 1940'larda yaklaşık 13 milyon kişi bu dili konuşuyordu. Ayrıntılı bilgi için bk. Dovid Katz, "Yiddish Language", The Yivo Encyclopedia of Jews in Eastern Europe, (Erişim 02 Şubat 2020), https://yivoencyclopedia.org/article.aspx/Language/Yiddish.

37 Rabinowicz, The World of Hasidism, 184.

38 Altshuler, Messianic Secret of Has., 4-5; Elior, The Mystical Origins of Has., 126, 146; Rabinowicz, The World of Hasidism, 184; Biale vd., Hasidism, 1; Kurt, Fundamentalist Yah., 275; Rosman, "The Rise of Hasidism", 7/643. 
Maggid'e göre tsadik'in iradesi Tanrı'nın iradesini yansıtır. Yaakov Joseph “Tsadik” inancının Kitab-ı Mukaddes'te Süleyman'ın Meselleri 10:25'te geçen, “tsadik dünyanın temeli ya da köşe taşıdır" anlamına gelen "tsadik yesod olam" ifadesine dayandığını ifade eder. "Temel" anlamındaki "yesod" kavramı Kabala sisteminde sefirotlardan dokuzuncusunun adıdır ve onun aracılığıyla ilahi lütufların yer yüzüne aktığı kabul edilir. Buradan hareketle tsadikin de yesod sefirasının yeryüzündeki fonksiyonunu ifa ettiği belirtilir. Bu durumda Tevrat'ta yer alan ifade Kabala mistisizmindeki görüş ile birleştirilerek Hasidizm tarafından yeni bir biçimde yorumlanmış, farklı bir felsefeyi ifade eder hale getirilmiştir. Tsadik aynı zamanda sema ile yer arasındaki merkezi sütun olarak her iki alemin iletişiminde aracılık yaptığı, hatta Yakup'un rüyasında yer alan, üzerinden meleklerin inip çıktığı yer ile gök arasındaki merdiven mesabesinde olduğu (Merkaba Mistisizmi) ve tsadikin iki dünya arasında gidip gelebilen yegâne kişi olduğu ifade edilmiştir. ${ }^{39}$

Tsadikler henüz çocuk sayılabilecek yaşlarında göreve gelebiliyorlar; yaşam biçimleri birbirinden farklı olabiliyordu. Örneğin Israel Friedmann çok şık giyinirdi. Evi saray gibiydi; burayı süslemek için başka ülkelerden sanatçllar gelirdi. Dört atın çektiği bir arabaya binerdi. Rebbe Mordedai de lüks içinde yaşayanlara bir diğer örnektir. R. David Talna, üzerinde "Davud, İsrail Kralı" yazan altından bir tahtın üzerinde oturuyordu. Turisk'li Abraham ise yapımı yıllar süren, altın ve gümüșten imal edilmiş nadir bir "menora"ya sahipti. 40 Ancak tsadik insanlar tarafından dünya zevklerine dalmış, şöhret ve servet peşinde koşuyor gibi gözüktüğü durumlar söz konusu olduğunda bunun bir illüzyon olarak değerlendirilmesi gerekir. Tsadikin her durumlarda ilahi bir görev içerisinde olduğu bilinmelidir. ${ }^{41}$

Tsadiklerin bir başka özellikleri de Tevrat'ı içinde bulundukları manevi hale göre diledikleri gibi yorumlayabilmeleridir. Çünkü onların kişiliği dini bir değer, Tevrat'ın yaşayan inkarnasyonu ya da "Yaşayan Tora" olarak görülür. Onun her sözü ve her hareketi ilahi hikmetin bir parçası olarak değerlendirilir. Yaşamı dini anlamda bir ehemmiyet taşımaktadır. Bu sebeple Dov Ber (Maggid) ile ilgili bir hasid'in şu sözleri önemlidir: "Ben Maggid'e Tora öğrenmeye değil, bağcıklarını nasıl bağladığını görmek için gittim.” Bu durum Hıristiyanlıktaki İsa'nın bizzat ete kemiğe bürünmüş vahiy olmasını çağrıştırmaktadır. ${ }^{42}$

Tsadik ve hasidin karşıllıklı ilişkileri söz konusudur. İbranice ve Arapçadaki harflerin harekeler olmadan sessiz kalması ve harekelerin de harfler olmadan anlamsızlaşması gibi, aynı şekilde Tsadik ve hasid için de durum böyledir. Bir tarafın inancı, bağlılığı ve sadakati diğer tarafın da canı gönülden onunla ilgilenmesi ve onu iç alemine çekip alması "hitkașerut ve hitkalelut" kavramlarıyla ifade edilir. Bu ilişki

39 Buber, The Origin and Meaning of Has., 141-142; Caravella, The Mystic Heart of Jud., 418-420; Kohler - Ginzberg, "Baal Shem Tob", 2/385; Louis Jacobs, "Basic Ideas of Hasidism ('Hasidism' içinde)", Encyclopaedia Judaica (USA: Macmillan Reference USA, 2007), 8/409; Rabinowicz, The World of Hasidism, 185.

$40 \quad$ Rabinowicz, The World of Hasidism, 120-122, 130, 186.

41 Martin, A History of Jud., 2/178-179.

42 Caravella, The Mystic Heart of Jud., 423, 436-437; Kurt, Fundamentalist Yah., 271. 
aslında Hz. Musa ile İsrailoğulları, bakıcı ve bebek, ebeveyn ve çocuk, çoban ve sürüsü, yaratıcı ve mahlukat arasındaki ilişkiye benzemektedir. Bu ilişki Kitab-ı Mukaddes'te İşaya 49:23'te şöyle anlatılır: "Krallar size babalık, prensesler sütannelik yapacak..." 43

Tsadik inancı ile mesih inancı arasında ilişki kurulabilir. Mesih aracıllğıyla tüm Yahudilerin topyekûn kurtuluşu düşüncesinin tsadik rolüyle değişerek bu görevin tsadiklere dağıtıldığı söylenebilir. Çünkü tsadiklerin gücü sadece kendi topluluğu ve dönemi için geçerlidir. Onlar kendi cemaatlerindeki insanların bireysel olarak kurtuluşuna aracılık ederler. Bu inancın Sabatay Sevi hareketi sebebiyle tam anlamıyla şoka uğramış ve yüz üstü bırakılmış bir topluluğun içerisinde ortaya çıktığı düşünüldügünde kendileri ile ilgilenip onları tekrar toparlayarak içinde bulundukları kaotik durumdan çıkaracak fonksiyonda birisine ihtiyaç duymalarından doğduğu ifade edilebilir. Bölge halkının kendileri adına tüm sorumluluğu alarak onları her türlü yönlendirecek bir yönetici modeline ihtiyaç duyduğunun bir göstergesi Frankistlerin Jacob Frank'a karşı tutumlarında görülebilir. Zaten tsadik'e yüklenen bir başka özellik de bu düşünceyi destekler. Buna göre tsadik, hem müritlerinin günahlarının bağışlanmasına aracı olur hem de onların kötü düşüncelerini iyiye dönüştürür. "Yerida letzoreh aliya" denilen, "yükselmek için alçalmak" şeklinde ifade edebileceğimiz inanca göre kötülügün üstesinden gelebilmek için onan yakın olmak gerekmektedir. Gazze'li Nathan’ın ileri sürdüğü “Mesihin kötülüğü yenmesi için onunla birleşmesi gerektiği” düşüncesi S. Sevi'nin -daha sonraları da J. Frank- din değiştirmesinin yarattığı travmatik durumun izahı için kullanılmıştır. Bununla toplumun Sevi ve Frank'ın din değiştirmesi ile yıkılan umutları diri tutulmaya çalışılmış, kurtuluşun hala mümkün olduğu hissi bu topluluklara anlatılmıştır. ${ }^{44}$

\subsection{Kabala'ya Yaklaşımları}

Sabatay Sevi ve Jacob Frank hareketlerinin Kabala'dan beslenerek ortaya çıkışı ve neticede Yahudi toplumda yarattığı hayal kırıklığı Kabala mistisizmine karşı farklı tutumun geliştirilmesine neden oldu. Birinci grup hiçbir şey olmamış gibi çizgilerini sürdürme eğilimindeki Ortodoks Kabalacılardı. İkinci grup ise yaşanan olumsuzlukların etkisiyle Kabala'yı toplum hayatından uzaklaştırarak belli eğitim düzeyine ulaşan insanların kırk yaşından sonra meşgul olabilecekleri ya da toplumla esnek bir bağı olan mistiklerin çevrelerinde uygulanır hale getirmekti. Geleneksel rabbâni çevrelerin yaklaşımı bu şekildeydi. Üçüncü tutum ise Kabala düşüncesini yeniden ele alarak ve revize ederek tüm Yahudi toplumu için bir canlanma ve yenilenme için kullanmayı amaçlayan Hasidiklerin yaklaşımıydı. ${ }^{45}$

Solomon Poll, "The Charismatic Leader of the Hasidic Community: The Zaddiq, the Rebbe", New World Hasidim, ed. Janet S. Belcove-Shalin (USA: State Univ. of New York Press, 1995), 273-274; Elior, The Mystical Origins of Has., 134-139; Caravella, The Mystic Heart of Jud., 425; Rabinowicz, The World of Hasidism, 121.

$44 \quad$ Dan, "Hasidism", 6/3790; Buber, The Origin and Meaning of Has., 42.

45 Gershom G. Scholem, Major Trends in Jewish Mysticism, (New York: Schocken Books, 1974), 1819; Caravella, The Mystic Heart of Jud., 400; Elior, The Mystical Origins of Has., 86-90; Dan, "Hasidism", 6/3786. 
Hasidizm Kabala felsefesinden önemli ölçüde etkilenmiş ve beslenmiş olmakla birlikte Kabala geleneğindeki bazı kavramları alarak kendi sistemi içerisinde dönüştürmüş, onlara farklı anlamlar yüklemiştir. Kabalacılığın sembolizmini, züht hayatını ve ibadetlerindeki karmaşık usulleri değiştirerek "neşe, eğlence" temelli bir anlayış getirmiş, sadece elitler için gizli bir doktrin halinde görülen Tanrıya ulaşmayı değiştirerek "tsadikler" aracılı̆̆ıyla herkesin ilahi âlem ile irtibat kurabileceği düşüncesini geliştirmiştir. Sosyal açıdan kabalistler münzevi bir şekilde küçük gruplarıyla ilgileniyorken tsadikler tüm toplumla ilgilenmiştir. Ayrıca Kabala düşüncesindeki kozmolojik boyutu dikkate almayıp tamamen teosofik ve pratik bir kabala anlayışını getirmiştir. 46

Hasidizm, ortaya çıkışından itibaren Sabatay Sevi ile alevlenen mesianik düşünceye karşı bir hareket olarak görülmüştür. Martin Buber (1878-1965) Hasidizm'in Kabala'yı dini hayatın içerisinde bir unsur haline getirdiğini, mistik fikirleri dindarların dünyasında ete kemiğe büründügünü ve tsadik anlayışıyla toplumu șekillendirdiğini ifade etmiştir. Buber'e göre "avoda begaşmiyut" denilen maddi dünya aracılığıyla Tanrıya ibadet anlayışıyla Hasidizm asketik yaşama mesafeli durmuş, ayakları bu dünyaya basan bir sistem inşa etmiştir. Gershom Scholem benzer şekilde Hasidikliğin Kabala felsefesinden beslense de onda yer alan Mesih ile topluca kurtuluş fikrini bireysel kurtuluş ile değiştirdiğini; tsadikler yoluyla Kabala'yı sıradan insanların gündelik dini hayatlarının bir parçası haline getirdiğini ifade eder. Scholem ayrıca Hasidizmin Kabala konusunda "fenâ hali" diyebileceğimiz gerçekliğin ortadan kalkmasını anlatan "bittul ha-yeş" kavramıyla, "devekut" denilen Tanrıyla vecd halinde mistik birliktelik kavramlarında önemli değişiklikler yaptığını ifade eder. ${ }^{47}$ Kabala düşüncesinde "devekut", "ilahi olana yönelik sabit ve sürekli bir odaklanma" iken BeŞT ile birlikte Hasidizm'de devekut "vecd halinde mistik bir deneyim" olarak bütün ibadetin temel amacı olarak görülür. Öncesinde "devekut" Şehina ile ilişki kapsamında düşünülüyorken Hasidizm'de artık doğrudan Tanrı'ya ulaşmayı ifade eder hale gelir. Devekut sadece seçkinler için değil, herkes için gerekli görülür. Devekut'a bilgi ve riyazet ile değil, mutluluk ve neșe haliyle bu dünya hayatı ile iç içe iken ulaşılacağına inanılır. 48

Hasidizm "kavana" (niyet, yoğunlaşma) öğretisinde de belli değișiklikler yapmıştır. Kavram Kabalacı çevrelerde âlemin yeniden tanrısal özüne geri dönmesi sürecine katkıda bulunan kozmik bir eylem olan "tikun"; rabbâni çevrelerde gönülden samimiyetle ibadete yönelme; Hasidikler arasında ise kişinin vecd halinde zihinsel yoğunlaşma ile (kavana) Tanrı'nın huzurunda olduğunu hissettiği ruhsal bir

\footnotetext{
46 Caravella, The Mystic Heart of Jud., 400, 425; Shaul Magid, Hasidism on the Margin (Madison: The University of Wisconsin, 2003), 74; Rosenthal - Dubnow, "Hasidism", 6/252. Altshuler, Messianic Secret of Has., 3-4; Biale vd., Hasidism, 4-5.

Immanuel Etkes, The Besht: Magician Mystic and Leader, trc. Saadya Sternberg (USA: Massachusetts: Brandeis University Press, 2005), 114-123; Kohler - Ginzberg, "Baal Shem Tob", 2/384; Kurt, Fundamentalist Yah., 200, 216-218, 264-265; Caravella, The Mystic Heart of Jud., 428; Rivka Shatz-Uffenheimer, “Teachings of Hasidim ('Hasidim' içinde)", Encyclopaedia Judaica (USA: Macmillan Reference USA, 2007), 8/413.
} 
dönüşümü ifade etmektedir. Bunun için Kabalistler kelimeleri belli sıra ile söyleyerek sefirot'lardan birine yoğunlaşmak suretiyle ilahi alanda özel bir etki elde etmek biçiminde mekanik bir ibadet ve dua biçimleri uygularken, hasid için dua Tanrıdan zevk almanın bir biçimidir. Kişi yoğunlaşarak (kavana) dua ettiğinde bu onu Tanrıya ulaştırır. Hasid için amaç kavana halinde dua etmektir. ${ }^{49}$

Kısaca Kabala felsefesinden hareketle kurtuluş, mesihi çağın gelmesi, Şehina'nın sürgünden kurtarılması ve mahlukattaki ilahi özlerin aslına döndürülmesi vb. söylemlerin ortaya çıkardığı bölünmelerin Yahudi cemaati olumsuz etkilediği bir dönemde, bunun önüne geçmek için herkesin Kabala'yla ilgilenmesi rabbiler tarafından yasaklanmıştır. Hasidizm bu yasakları dikkate almamış, Kabala'nın temel kavramlarını yeniden anlamlandırarak Kabala'yı bir dini pratiğe dönüştürmüş; sıradan halk tabakalarının dini yaşamlarının bir parçası haline getirmiştir. $\mathrm{Bu}$ bağlamda kâinatın Tanrının yüceliği ile dolu olduğu, canlı-cansız her varlıkta O'ndan bir parça bulunduğu, her șeyin Șekina'nın bir uzvu mesabesinde görüldüğü ve herkesin potansiyel olarak Tanrı ile manevi bir birlik yaşayabileceği düşüncesi ibadet anlayışlarına yansıyarak dua ya da gündelik hayatta yapılan her düşünce ve eylemin kişiyi Tanrı'yla birliğe götüreceği şeklinde bir inanca kapı aralanmıştır. Bütün bu yaklaşımlar insan ve Tanrı arasındaki ilişkinin algılanması ile ilgili paradigmayı değiştirmiştir. Kısaca Hasidizm "Kişi devekut ile daima Tanrı ile irtibat halinde olmalıdır. Kişi bilmelidir ki Tanrıyla sürekli irtibatlı olmak ve ona ibadet etmek tüm evreni eski saflığına yükseltecektir" diyerek mistisizmi herkesin elde edebileceği evrensel bir miras haline getirmiştir. Bu ruhani değișim bir sosyal değişimi de sağlamıştır. ${ }^{50}$

\subsection{Yeni Dini Söylem ve Uygulamaları}

Hasidizm Kabala felsefesinin beslediği asketik din anlayışına ilaveten geleneksel Yahudiliğin şekilci din anlayıșına da karşı çıkarak dini duygu, coşku ve imanın vurgulandığı farklı bir dini yaşam ileri sürmüştür. ${ }^{51}$

Hasidik anlayışta dini hayatın temeli akıldan ziyade duygulardır. Teolojik ve fıkhi eğitim ikinci plandadır. Ahlak kitapları okumak Talmud ve Rabbâni eserlerle uğraşmaktan daha yararlıdır. Şekilsel ritüellerden ziyade kişiye manevi bir duygu veren faaliyetler daha önemlidir. Bu yönüyle Hasidizm, dini hayatın merkezine dini dogmalar ve ritüeller yerine inanç ve maneviyatı yerleştirmesiyle Hıristiyanlığın Protestan öğretisiyle benzeşir. ${ }^{52}$

Hasidik hareketin üç erdemi vardır. Birincisi "simha" olarak ifade edilen 'neşelilik'tir. Hasidiklere göre üzüntülü bir şekilde ya da kendine zarar vererek kişinin

\footnotetext{
49 Martin Buber, Hasidism and Modern Man, trc. Maurice Friedman (New York: Harper Torchbook, 1966), 98-108; Kurt, Fundamentalist Yah., 210, 214; Caravella, The Mystic Heart of Jud., 431.

50 Elior, The Mystical Origins of Has., 147. Ayrıca bk. Magid, Hasidism on the Margin, 78; Kohler Ginzberg, "Baal Shem Tob”, 2/385.

$51 \quad$ Kohler - Ginzberg, "Baal Shem Tob”, 2: 384; Kurt, Fundamentalist Yah., 265.

52 Rosenthal - Dubnow, “Hasidism”, 6/252-253.
} 
Tanrı'ya ibadet etmesi mümkün olmadığından asketizm yasaktır. Hasidik hareketin "neşe" vurgusu BeŞT'in hayatından çeşitli menkıbelerle anlatılır. Hasidiklere göre neşe, Tanrı-insan ikiliğini ortadan kaldırarak "vahdet"e (yihud) sebep olur, Tanrı'ya neșeyle ibadet edilmemesi büyük günahtır. ${ }^{33}$ İkinci erdem 'tevazu ve mutedil olma' anlamına gelen, "şiflut"tur. Buna göre gurur, kibir ve kendini beğenme bir hasid'in yaşamında yer alamaz. Üçüncü erdem ise "dini şevk, coşku" anlamına gelen "hitlahavut"tur. Buna göre kişi ilahi ateşle yanıp tutuşmalıdır. ${ }^{54}$

Hasidizm dini uygulamalar ile ilgili usul ve ibadetlerin icrasında çeşitli farklılıklar getirmiştir. Bölgede uygulanan Aşkenaz ibadet usulünde değişiklik yaparak Polonya Așkenaz geleneği, Filistin Sefarad geleneği ve Luria'nın yorumlarının bir karışımını uygulamaya başlamıştır. Ayrıca pek çok dini uygulamada yeni usuller geliştirdiklerini ifade edebiliriz. Sabah duasında iki çift tefillin takmaları, Pesah Bayramı'nda sadece "matsa" denilen mayasız hamurdan yapılan bir tür peksimet yemeleri, Seder yemeğinde dört kadeh yerine beş kadeh şarap içmeleri, Roş HaŞana'da "şofar" çalınması ile ilgili farklı uygulamaları örnek olarak zikredilebilir. ${ }^{55}$

Hasidikler tsadikler ile ilgili menkıbeleri okumayı dua etmeyle eş değer görürler. "Sippurim" adı verilen bu menkıbeler genelde büyük saraylar, şeytanlar, cadılar, hayaletler, krallar ve prensler gibi masalsı kahramanların bolca yer aldığı kurgusal anlatılardır. Menkıbelerden bazılarının çeşitli halk hikayelerinden, Hindistan mistikleri ve İslam mutasavvıflarının menkıbelerinden alındığı kaynaklarda yer almaktadır. Bunların anlatılmasının amacı tsadiklere yönelik muhabbeti artırmaktır. ${ }^{56}$

Dua ile ilgili yapılan bir başka değişim ise kişiyi üzüntülü ve kederli ruh halinden kurtaracağı düşüncesiyle dua öncesi ve sonrasında içki içilmesidir. Onlar için dua Tanrı'dan bir şeyler istemek değil, kişinin her daim Tanrı'yla birlikte olduğunu hissetmesi, Tanrı'dan ayrı bir varlı̆̆ olduğu fikrini terk etmesidir. Yahudiler geleneksel olarak dua sonrasında Mişna'dan bir bölüm seçerek çalışırken Hasidikler'in içki içmesiyle ilgili Rizhyn'li R. Israel şöyle bir izah yapar: “Onlar duayı o kadar donuk ve şevksiz bir şekilde, ölü gibi icra ediyorlar ki sonrasında oturup Mişna çalışabiliyorlar. Oysa biz son derece canlı, neșe dolu şekilde dua ediyoruz. Canlı ve neşeli insanlar da bir şeyler içmeye ihtiyaç duyarlar." 57

Hasidikler geleneksel Yahudi sinagog ibadetinden farklı bir şekilde hareket ediyorlardı. Sinagog ibadetinde kişilerin oturarak sessizce okunanları dinlemesi, sadece duanın ayakta okunan kısımlarına ayakta iştirak etmesi gerekiyorken

\footnotetext{
$53 \quad$ Martin, A History of Jud., 2/174; Kurt, Fundamentalist Yah., 223.

54 Martin, A History of Jud., 2/175-177; Kohler - Ginzberg, "Baal Shem Tob”, 2/385.

55 Rabinowicz, The World of Hasidism, 189-191; Rubinstein, "Hasidism”, 8/399.

56 Caravella, The Mystic Heart of Jud., 441-442; "Sippurim” ile ilgili bilgi için bk. Joseph Jacobs - Judah David Eisenstein, "Sippurim", The Jewish Encyclopaedia (New York and London: Funk and Wagnalls Company, 1905), 11/386-388; Baal Şem Tov'un mucizeleriyle ilgili örnekler için bk. Kohler - Ginzberg, "Baal Shem Tob”, 2/386.

57 Rabinowicz, The World of Hasidism, 187, 189; Jacobs, "Basic Ideas", 8/409; Kohler - Ginzberg, "Baal Shem Tob", 2/384-385; Kurt, Fundamentalist Yah., 198-199.
} 
Hasidiklerin ibadet esnasında taklalar atmak, ayakkabılarını çıkarıp fırlatmak, amuda kalkmak, Tanrı'nın yasak ismini söylemek ya da elleri üzerinde durmak gibi hareketler yaptıkları kaynaklarda anlatılmaktadır. Bazen duayı yarıda keserek neşelenmeye çalışır; bunun için Yiddişçe anlamsız bazı kelimeler bağırıp çağırırlardı. Hasidikler bu davranışları eleştirenlere, bahsedilen davranışların kavana halinde şuurlu olarak yapılmadığı, her grupta veya herkeste bunların görülmediği şeklinde izahlarda bulunmaya çalışmışlardır. ${ }^{58}$

Hasidizmde ibadet esnasında eğlenceli olmak gerektiği için müzik ve dansa özel anlamlar yüklenir. Bunlarla ruhların temizlendiği, kişilerin manevi olarak yükseldiği, topluluğun birbirlerine sıkıca bağlanmasına vesile olduğu ve sosyal ilişkileri geliştirdiğine inanılır. Ancak bu konuda tarihi süreç içerisinde bir dizi gelişmeler olmuş, bazı cemaatler ibadet esnasında dansa yer vermezken bazıları ise eskiye oranla çok daha sınırlı şekilde yer vermektedir. Günümüzde dansın uygulanışı gruplara göre farklılık göstermektedir. ${ }^{59}$

Hasidizmin getirdiği önemli yeniliklerden birisi günlük işlerin ibadet olarak telakki edilmesidir. "Madde ile ibadet etmek" anlamına gelen "avoda begaşmiyut" kavramı bu düşünceyi anlatır. Düşüncenin temelinin Özdeyişler 3:6'daki "Her yolla Tanrı'yı bilmelisin" ifadesi ile Mezmurlar'daki "Tüm kâinat Tanrının yüceliği/ihtişamı ile doludur ve bunun olmadığı hiçbir yer yoktur" ifadesi olduğu belirtilir. Ayrıca bu hususta BeŞT'in Enoh ile ilgili kaynaklarda yer alan şu yorumunu kullanırlar: Enoh ayakkabı tamircisidir ve deri dikerken her dikişinde Tanrı ve O'nun Şehinası ile birlik yaşamaktadır. Çünkü Tevrat'ta “Ellerinin yapacağı her şeyi kuvvetle yap” buyurulur. BeŞT bu pasukta geçen “kuvvetle yap” ifadesini ruhunla ve düşüncenle Tanrı ve O'nun Şehina'sıyla bir olarak yapmak şeklinde yorumlar. Kısaca bu bakış, kişinin belli bir manevi hal üzere olduğu taktirde yapacağı alelâde işlerin bile ibadet olacağıdır. ${ }^{60}$

Hasidizm'in ortaya çıkardığı hususlardan bir tanesi de kişilerin ibadet sâikiyle "tsadik" denilen manevi liderleri bir tür hac formatında ziyaret etmeleridir. Aslında Yahudilikte bayramlarda, ay başlarında ve Şabatlarda kişinin hocasına saygı göstermesi Talmud'da yer alan dini sorumluluklardandır. Bu ziyaretlerde tsadik ile özel görüşmeler yapılır, günahlar itiraf edilerek kefaret için nelerin gerektiği ile ilgili tavsiyeler alınır, şefaat talebinde bulunulur, günlük hayatla ilgili problemler için görüş istenirdi.61

Tsadiklerin Şabat günü "Tiş" adı verilen ayinsel bir özelliği olan yemek düzenleyerek hasidler ile birlikte olması Hasidiklerin yeni uygulamalarından bir

\footnotetext{
58 Rosman, "The Rise of Hasidism", 7/636; Kurt, Fundamentalist Yah., 180-181; Wilensky, "HasidicMitnaggedic Polemics", 257-259.

59 Yaakov Mazor, "Hasidism: Dance", The Yivo Encyclopedia of Jews in Eastern Europe (Yivo Institute for Jewish Research), (Erişim 26 Şubat 2020), https://yivoencyclopedia.org/article.aspx/Hasidism/Dance. Buber, The Origin and Meaning of Has., 84-86; Elior, The Mystical Origins of Has., 78-79; ShatzUffenheimer, "Teachings of Has.", 8/411.

61 Rosman, "The Rise of Hasidism", 7/634; Rabinowicz, The World of Hasidism, 186-187.
} 
diğeridir. Rebbe yemek sonrasında bir sohbet yapar, devamında cemaat "zemirot"62 denilen ilahilerle "niggun ya da nigunim"63 denilen sözlü-sözsüz ezgiler, eğlenceli melodiler söyleyerek eğlenir. Bu sırada rebbe'yi seyretmek, her jest ve mimiğini dikkatle takip etmek çok önemli görülürdü. Rebbe'nin yemeğinin kalıntılarını toplamaya ve paylaşmaya büyük değer verilir, rebbeler kendileri bazen bir tabaktan çok az tadarak bunu masaya uzatırlar; "şrayim" denilen artıklar masadakiler tarafından büyük bir şevkle paylaşılırdı.64

Hareketin ortaya çıkışından itibaren hasidik grupların İsrail'e göç etmek gibi bir gayelerinin olmadığını görüyoruz. Kaynaklarda BeŞT'in Kutsal Topraklara bir seyahat planladığı ancak yarı yolda bu düşüncesinden vaz geçtiği anlatılmaktadır. İlk dönemlerde sadece Dov Ber'in iki talebesi Vitebsk'li Menahem Mendel ve Kalisk'li Abraham, 1777 yılı civarında İsrail'e göç etmiştir. Doğu Avrupa'da ortaya çıkan büyük siyasi çalkantılara bağlı olarak 20. ve 21. yy.'da yapılan göçlerde de öncelikli rota İsrail olmamış, ABD ve Kuzey Amerika daha fazla tercih edilmiştir.65 Bunun teolojik nedenleri vardır. Çünkü Hasidik Yahudiler için sürgün hayatı aslında yaratılış sürecinde tüm dünyaya dağılmış olan kutsal kıvılcımların toplanması için gereken bir süreçtir. Miladi 1.-2. yy.'da yaşamış Rabbi Akiva döneminden beri Yahudilerin sürgünde nerede olurlarsa Şehina'nın orada Yahudilerle birlikte olduğu inancı kaynaklarda yer almaktadır. Bu sebeple sürgünün kurtuluş için ilahi bir gereklilik/kader olduğu; Yahudilerin sürgün hayatının bilinci içerisinde yaşamaları gerektiği, ev almak vb. şekillerde bu şuurdan uzaklaşacakları tutumlardan kaçınmaları gerektiği ifade edilmiştir. Yine Pesah Bayramında yenen Seder yemeğinde söylenen "gelecek sene Kudüs'te" ifadesi bu ruh halinin tezahürü olarak görülebilir.66

Hasidizm'in farklı uygulamalarından birisi de koşer kapsamındaki "Şehita” adı verilen hayvan kesimidir. Bu husus herem fetvalarının başlıca konuları arasında yer almıştır. Hasidiklere kesimde son derece keskin bıçaklar kullanmaları suretiyle bu konudaki dini hükümleri çiğnedikleri eleştirisi yapılmış. Ancak bu tartışmada sadece çok keskin bıçaklar kullanarak kesim yapmalarından ziyade konunun farklı boyutları söz konusudur. İşin ekonomik boyutunun olması, bu itirazların her bölgede

62 "Zemirot" ile ilgili bilgi için bk. Joseph Jacobs - Francis L. Cohen, "Zemirot", The Jewish Encyclopaedia (New York and London: Funk and Wagnalls Company, 1906), 12/656-660.

63 Judith Frigyesi, "Music: Music for Sacred Texts", The Yivo Encyclopedia of Jews in Eastern Europe (Yivo Institute for Jewish Research), (Erişim 28 Şubat 2020), https://yivoencyclopedia.org/article.aspx/Music/Music_for_Sacred_Texts. Ayrıca bk. Ellen Koskoff, "Language of the Heart: Music in Lubavitcher Life", New World Hasidim, ed. Janet S. Belcove-Shalin (USA: State Univ. of New York Press, 1995), 91. Rubinstein, "Hasidism", 8/408; Louis Jacobs, "Hasidism: Everyday Life”, The Yivo Encyclopedia of Jews in Eastern Europe (Yivo Institute for Jewish Research), (Erişim 28 Şubat 2020), https://yivoencyclopedia.org/article.aspx/Hasidism/Everyday_Life. Dan, "Hasidism", 6/3788. Ayrıca bk. Assaf, "Historical Overview", 1/663, 667. Rubinstein, "Hasidism", 8/395.

66

Leifert, "The Role of Messianism", 123-124; Janet S. Belcove-Shalin, "Home in Exile: Hasidism in the New World", New World Hasidim: Ethnographic Studies of Hasidic Jews in America, ed. Janet S. Belcove-Shalin (USA: State Univ. of New York Press, 1995), 209. 
yapılmıyor olması, uygulamanın Sabataycılık șüphesi ihtiva etmesi bu boyutlara örnek olarak zikredilebilir. ${ }^{67}$

Mesih beklentisi ya da mesih önderliğinde toplu bir kurtuluş düşüncesiyle ilgili Hasidizm bazı farklı yaklaşımlar sergilemiştir. Maggid bireysel olarak tefekkürle kurtuluş vurgusu yaparken Bratslav'lı R. Nahman ise Mesih önderliğinde toplu bir kurtuluşu daha ön planda tutar; kendi ruhunun Mesihin ruhu olduğunu iddia ederek kurtuluşun onun yaşamı sırasında gerçekleşeceğine dair büyük umut içindedir. $\mathrm{Bu}$ yaklaşımlardan hareketle Hasidizm'de Mesih beklentisi inancıyla ilgili bir şüphe duyulmamakla birlikte bu beklentiyi dini ve gündelik hayatın merkezine yerleştirmemek ile Mesihin gelişini hızlandırmak için bir dizi çaba içerisinde olmak şeklinde iki temel yaklaşımın sergilendiğini; Maggid'in birinci kısım için, R. Nahman'ın ikinci kısım için örnek olduğunu ifade edebiliriz. ${ }^{68}$ Ancak bireysel kurtuluş vurgusu ön plandadır. Buna rağmen 1812'de Napolyon'un Rusya'yı işgal etmesi hadisesi, mesihin gelişi öncesi büyük bir savaşın çıkacağı fikrine bağlı olarak Bratslav'lı Nahman ve bazı hasidik liderlerin mesianik faaliyetlere girișmesini sağlamıștır. Modern dönemde de $\mathrm{CHaBaD}$ grubu yakın bir mesianik kurtuluşun dini emirlere sıkı sıkıya bağlı kalmakla gerçekleşeceğini vurgulayarak yedinci rebbeleri Menahem Mendel Schneerson'un mesianik bir rolü olduğunu, hatta öldüğü 1994 yılından sonra bile bu rolünü sürdürdüğünü ifade etmektedir.69

Konunun bir diğer boyutu ise Hasidizm'deki tsadiklerin bir tür mesih fonksiyonu icra etmeleridir. Ancak tsadik ile mesih inancı aralarında bazı temel farklılıklar vardır. En başta aynı anda onlarca tsadik görev yapmaktadır. Baal Şem Tov'a göre faaliyetini açıktan yürüten 36 tsadik olduğu gibi gizli olarak yürüten de 36 tsadik bulunmaktadır. Ayrıca tsadiklerin gücü kendi cemaatleri ile sınırlıdır. Dolayısıyla daha önce ortaya çıkan (sahte) mesihlerde olduğu gibi bir kişinin çıkarak tüm toplumu yönlendirmesi söz konusu değildir.70

\subsection{Günümüzde Geleneklerini Korumaları/Sürdürmeleri}

Yahudiler isimlerini, dillerini ve kıyafetlerini korumayı asimile olmadan kalabilmelerinin gereği olarak görürler. Bu durumu Mısır Sürgünü'nden başlayarak Yahudilerin vatanlarından uzak yaşadıkları her yerde geçerli görerek, bunların muhafazasını Talmudik bir emir olarak kabul ederler. Bu konularda geleneksel

67 Konu ile ilgili tartışmaların ayrıntılı değerlendirmeleri için bk. Wilensky, "Hasidic-Mitnaggedic Polemics", 253-257.

68 Leifert, "The Role of Messianism", 124-125.

69 Dan, “Hasidism”, 6/3788-3789. Bu savașta Şneur Zalman'ın Rusya'yı desteklerken taraftarlarına Rusya lehine casusluk yapmalarını salık verme gerekçesi şöyledir: "Şayet Napolyon kazanırsa İsrail'in zenginliği artacak ve büyüklüğü ortaya çlkacak. Bu da dünya sevgisi ile İsrail'in kalbini Tanrı' dan uzaklaştıracak." Ayrıntılı bilgi için bk. Rubinstein, "Hasidism", 8/396. Ayrıca bk. Aviezer Ravitzky, "The Contemporary Lubavitch Hasidic Movement: Between Conservatism and Messianism", Accounting for Fundamentalisms: The Dynamic Character of Movements, ed. Martin E. Marty - R. Scott Appleby (Chicago and London: The Univ. of Chicago Press, 1994), 303, 313320.

70 Buber, The Origin and Meaning of Has., 43-44. 
çizgilerinden ayrılarak diğer milletlere benzemeyi "kelifa gedola" ifadesiyle "kötü ruh/şeytan işi" olarak tasvir ederek reddederler. ${ }^{71}$

Genel yaklaşım bu olmakla birlikte Hasidik hareketin ortaya çıkışı ile günümüzdeki profili dikkate alındığında, tarihsel süreçte Haskala ile başlayan ve irili ufaklı sosyal ve siyasi pek çok kriz sonrasında mevcut şekle büründügünü ifade etmek gerekir. Günümüzdeki Hasidik kimliği 19. yy.'dan başlayarak bugüne kadar devam eden modern ve seküler dünya görüşü ile aktif mücadele boyunca oluşmuştur. ${ }^{72}$

Hasidizmin geleneksel değerlerine sahip çlkma konusundaki önemli etkenlerden birisi, özellikle Avusturya bölgesinde 18. yy.'ın sonu ile 19. yy.'ın başlarında başlayan Yahudilerin Almanlaştırılması teşebbüsleridir. Bu kapsamda Yiddiş Dili yasaklanmış, bu dilde yazılan dokümanlar devlet dairelerinde kabul edilmemiş, evlenmek için başvuran çiftlerin Almanca sınavına tabi tutuluştur. Hasidizm, kendini korumak ve kültürel asimilasyona uğramamak için Almanca öğrenme, seküler eğitim alma ve Haskala hareketinin tezlerine karşı çıkmayı bir zorunluluk olarak görmüş, devlet yöneticilerin Yahudilere yaptığı baskılardan onları sorumlu tutmuştur. Bu aşırı korumacı tutum bazen tıbbi tedavilere izin vermeme eğilimine kadar ileri gitmiştir. Bu yaklaşımın en çarpıcı örneklerden birisi de Yahudilerin diasporadaki yaşamlarının tamamen geçici bir durum olarak görülmesi sebebiyle, ev satın almanın kişiyi sürgün yurduna bağlayacağı ve asimile olmasına zemin hazırlayacağını ifade edilerek atalarının 400 yılı aşkın süre Mısırda çadırlarda yaşamayı tercih ettiklerinin vurgulanmasıdır. Kısaca Hasidizm'in kültürel asimilasyona ve Haskala hareketine karşı kendisini savunma çabası zamanla modern hayata, ya da Yahudilerin hayatlarının modernizasyonuna karşı bir tavra dönüşmüştür. ${ }^{73}$

2. Dünya Savaşı sonrasında New York Hasidizm için önemli bir merkez haline gelmiştir. Bu şehirde her ne kadar modern bir toplum içinde de olsalar da, kendi içlerinde dış dünyaya ihtiyaç duymayacak şekilde, orta çağ gettoları tarzında yapılar oluşturmuşlardır. Yahudiler buralarda gönüllü olarak yaşamaktadır. Borough Park, Williamsburg, Kiryas Joel ve New Square bu gettolara örnektir. 2013 rakamlariyla yaklaşık 132.000 yahudi hanesi ile Borough Park bunların en kalabalığıdır. Bu ailelerin yaklaşık \%68'i yıllık 50.000 doların altında kazanmakta, \%44'ü yerel makamlarca yoksul olarak tanımlanmaktadır. Sadece bu kısımda 200 kadar sinagog ya da ştibleh, yaklaşık 32.000 öğrencinin eğitim gördüğü farklı büyüklüklerde 77 yeşiva bulunmaktadır. Buralar dünyanın en büyük metropolünün içerisinde tamamen farklı yapıdaki küçük adacıklar gibidir. Buralarda farklı hasidik hanedanlıklar karışık olarak bulunmakta, her biri kendi teşkilatını oluşturmaktadır. Örneğin Satmar grubu New York'ta kendi sinagogları dışında cenaze hizmetleri, mikveler, kasap, fırın; içinde kendi okul sistemleri, iş acenteleri, hastane, bayan jinekolog kliniği, ambulans hizmetleri, özel bakım hizmeti, faizsiz kredi birimi, haftalık dergi ve kitap yayımlayan

Mahler, "Has. and the Jew. Enlightenment", 413.

Berger, The Pious Ones, 139.

Mahler, "Has. and the Jew. Enlightenment", 413-417, 423. 
basın yayın birimi bulunan kurumsal külliyeleri ve Brooklyn-Manhattan elmas merkezi arasında çalışan özel otobüs hizmetine sahiptir. ${ }^{74}$

Özellikle Satmar ve Lubavitch grupları New York Hasidik cemaatinin önemli kısmını oluşturur. Erkekler her mevsim uzun siyah pardösüleri, kravat takmadan giydikleri beyaz gömlekleri, geniş saçaklı fötr şapkaları, peyot ismi verilen favorileriyle; kadınlar boğazlarına kadar kapalı yakalı elbiseleri, dizlerinin altına uzanan etekleri ve evlilerin saçları örtmesiyle dikkat çeker. Erkek ve kız çocuklarının ayrı okullara devam ettiği kendi okul sistemleri içerisinde erkek ve kadınların tamamen ayrı şekilde yaşamlarını sürdürdükleri (haremlik- selamlık) bir yaşam biçimleri görülmektedir. İsrail'de ise Kudüs'te Mea Şearim, Tel Aviv'de Bnei Barak semtinde yoğun olarak yaşarlar. İsrail'deki en önemli hasidik grup Gur/Ger cemaatidir. New York ve İsrail dışında en önemli merkezleri Kuzey Londra'da Stamfort Hill ve Belçika Antwerp şehridir. ${ }^{75}$

Hasidik grupların günümüzdeki sayılarını incelediğimizde yaklaşık 26.000 aile ile tüm hasidiklerin yaklaşık \%20'sini oluşturan, Williamsburg, Brooklyn ve Kiryas Joel'de yaşayan ve Siyonizm karşıtllklarıyla bilinen Satmar grubu en kalabalığıdır. Lubavitz-ChaBaD grubunun 16.800 aile olduğu kendi kayıtlarında yer almaktadır. Bunların ardından 11.600 aile ile hasidiklerin \%9'unu oluşturan ve İsrailde yoğun olarak bulunan Ger grubu yer alır. 10.500 aile ile Vişnitz, 7.000 aile ile Belz, 4500 hane ile Bobov bunları takip etmektedir. ${ }^{76}$

Hasidik grupların çoğu, üyelerinin televizyon ve radyo kullanmasına, tiyatro ve sinemaya gitmeye izin vermemekte, hasidik olmayanların yazdığı gazete, dergi ve kitaplarını okumamalarını salık vermektedir. ${ }^{77}$ Örneğin Satmar, kendi grupları dışından herkese șüpheyle yaklaşır, yabancı biriyle konuşmayı tehlikeli ve riskli olarak görür, İsrail Devleti ve Siyonizm karşıtlıkları ile diğer pek çok Yahudiden ayrışır ve ayrı durur. Hatta bu grubun üyelerinden İsrail Devletinde yaşayanlar devletin herhangi bir kurumu ile iletişime geçmekten imtina etmektedir. Lubaviç grubu ise kendilerini "Yahudilere misyonerlik yapan Yahudiler" olarak görmekte ve özellikle seküler Yahudiler bașta olmak üzere diğer Yahudileri Ortodoks Yahudiliğe çağırmaktadır. Bratslav grubu, Boston Rebbesi Levi Yitshak Horowitz de benzer faaliyetler yürütmektedir. Hasidik grupların genelde modern yaşam şartlarından etkilenmeden geleneksel formlarını muhafaza etmekle birlikte özellikle $\mathrm{CHaBaD}$ grubunda yeni kuşaklarda kılık kıyafetlerle ilgili daha farklı tutumlar gözlemlenebilmektedir.78

\footnotetext{
74 Sharot, "Has. in Modern Society”, 516. Berger, The Pious Ones, 104-132.

75 Eli W. Schlossberg, The World of Orthodox Judaism (New Jersey\&London: Jason Aronson Inc., 1986), 13-14; Sharot, "Has. in Modern Society", 512-513; Van Loenen, "A Fresh Perspective", 16. 76 Ayrıntılı bilgi için bk. Marcin Wodzinski, Historical Atlas of Hasidism (Princeton, New Jersey: Princeton Univ. Press, 2018), 192-205.

77 Sharot, "Has. in Modern Society", 516.

78 Martin, A History of Jud., 2/187; Sharot, "Has. in Modern Society”, 514, 521, 526-527.
} 
Bugün Avrupa ve Amerika'daki Yahudilerin \%90'ı ile dünyadaki tüm Yahudilerin \%80'i Doğu Avrupa kökenlidir. ${ }^{79}$ Ortaya çıktığı dönemden itibaren kısa süre içerisinde Doğu Avrupa Yahudi topluluğu arasında süratle yayılan ve zamanla pek çok bölgede çoğunluğu oluşturacak kadar büyüyen bir hareket olan Hasidizm'in doğru anlaşılması özellikle ABD’de yaşayan Yahudileri daha iyi anlamak için son derece önem arz etmektedir.

Günümüzde Hasidik Yahudilik ABD'de her geçen gün büyümekte, yakında Amerika Yahudi nüfusunda çoğunluğu oluşturmaları beklenmektedir. Sadece Satmar grubunun New York ve çevresindeki okullarında 30000 öğrenci bulunmakta, bu sayı tüm ABD'deki Yeşiva talebelerinin 1/3'üne tekabül etmektedir. ABD'de Yahudi cemaat arasında seküler grup gün geçtikçe küçülmektedir. 1950'lerde günlük 100 000 okuyucusu olan Yiddiş Dilinde "Forward" isimli gazete çıkarabilen bu topluluğun gazetesi şu an haftalık 5000 okuyucuya sahiptir. Benzer şekilde seküler Yahudilerin 1950'lerde "Scholem Aleichem" ismiyle ve başka isimlerle çok sayıda okulları olup bunlar yoğun olarak seküler eğitim veriliyorken bu okullar günümüzde neredeyse tamamen ortadan kalkmıştır. Aslında pek çok düşünür 1950'lerde Ortodoks Yahudiliğin seküler dünyada eriyip asimile olacağını ön görüyorken durum tam tersine oldu. 2013 yılı Ekim ayında Pew Research Center'in ABD'deki Yahudi topluluk hakkında yayımladığı araştırmada karışık evliliklerin tüm Yahudiler arasında \%58'e yükseldiğini, Ortodoks olmayanlarda bu oran \%71'lerde iken Hasidikler ve diğer Ortodoks gruplarda yalnızca \%17 olduğu görüldü. Ayrıca kısa süre öncesinde Ortodoks Yahudilerin tüm Yahudiler arasındaki oranı \%10 civarında iken bu oran hızla büyümektedir. 18 yaşından küçük Yahudi çocukların \%27'si Ortodoks ailelerde yaşamakta iken 18-19 yaş aralığında bu oran \%11'dir. ${ }^{80}$

Hasidik cemaatlerin her geçen gün büyümesi ve Yahudi toplumun içerisinde oranlarının süratle yükselmesinin temel nedeni evlilik ve doğum kontrolüne yönelik politikalarıdır. Hasidik cemaatlerde erken yaşta evlilikler teşvik edilir. Kızlar genellikle 18-20, erkekler ise 20-22 yaşları arasındayken evlenir. Evlenecek çiftlerin düğün öncesinde belli ölçülerde görüşmelere izin verilse de çiftler bu süreçte birbirlerine dokunmazlar. Evliliğe karar verildiğinde tsadik'lerinin onayıla ailelerin öncülüğünde süreç tamamlanır. Yaratılış 1:28'de "Verimli olun ve çoğalın" ifadesinden hareketle doğum kontrolüne izin vermez; Sina'da Hz. Musa'ya verilen vahye muhatap olmak için bekleyen İsrailoğullarının ruhlarına bu firsatın sunulması için cinsellik ve çoğalma dini bir görev olarak görülür. Bunlardan hareketle hasidik ailelerin çok sayıda çocuğu olur. 2005 tarihli bir veride ABD'de bu ailelerin ortalama sekiz çocukları olduğu ifade edilmektedir. ${ }^{81}$

Rabinowicz, The World of Hasidism, 139.

Berger, The Pious Ones, 376-378.

Jack Wertheimer, "Jews and the Jewish Birthrate", aish.com, (Erişim 28 Şubat 2020), https://www.aish.com/jw/s/48899452.html; Sharot, "Has. in Modern Society", 523; Berger, The Pious Ones, 24-25; Jacobs, "Everyday Life". 
Hasidik Yahudilerin Amerika'ya bakışları olumludur. Ancak kendilerinin "Erime Potası" diye adlandırılan Amerika'da erimek istemediklerini, kültürel olarak kendi geleneklerine sahip çıkmak istediklerini, aksi durumun "manevi bir holokost" olacağını, asimilasyon ve karışık evliliklerin Yahudilere Hitler'den daha fazla zarar vereceğini, Hasidik grupların bu olumsuzluktan en az etkilenen Yahudi topluluğu olduğunu, bu yönüyle Amerikan Yahudiliğinin geleceğinin kendileri olduğunu vurgulamaktadırlar. ${ }^{82}$

Hasidik cemaatler, kendileri gibi modernizm karşıtı Hristiyan gruplar ile mukayese edildiğinde ilginç sonuçlar ortaya çıkmaktadır. Öncelikle onlardan farklı olarak sosyal güvenlik sistemi ve refahın tabana yayılması gibi hükümet programlarına iştirak ederek bu imkanlardan faydalanmakta, siyaset ile ilgilenerek yerel ve ulusal seçimlerde blok halinde hareket etmektedirler. Amişler, Mennonitler ya da Hutteritler gibi dışa kapalı bazı Hıristiyan mezhepleri de modern hayatı reddederek geleneksel yaşam biçimlerini sürdürmeye çalışmaktadır. Ancak bu grupların hasidiklerden temel farkları diğer toplumlardan uzak, toplu şekilde, kendi kendilerine yetecek şekilde planlanmış, dış dünyayla olabildiğince az bağlantı kurarak yaşamaya çalışmalarıdır. Bu topluluk üyelerinden modern yaşam biçimiyle muhatap olanlar genellikle grup aidiyetlerini ve kimliklerini kaybetmektedir. $\mathrm{Bu}$ sebeple Amişler teknolojik cihazları, araç-gereçleri reddetmekte, Hutteritler ise lüks sayılabilecek icatları reddetme, hayatlarını kolaylaştıracak tarımsal cihazları ise kabul etme eğilimindedirler. Hasidik cemaatler ise hayatı kolaylaştıracak teknolojik cihaz ya da aletlerle ilgili bu tür kısıtlamalardan uzak durarak modern hayatın ortasında, Dünya'nın en büyük metropollerinden birinin merkezinde kendi yaşam anlayışlarını ısrarla sürdürmektedir. ${ }^{83}$

\section{Sonuç}

Hasidizm'in Yahudi toplumda, Yahudiliğin temel kavramlarını kullanarak, ayrılıkçı bir yol izlemeden geleneksel bir Yahudinin inanç, ibadet ve sosyal yaşamı ile karşılaştırıldığında tamamen yeni bir sistem inşa ettiğini, bu yönüyle geleneksel yapı içerisinde yeni(likçi) ve yenileyici bir hareket olarak görülebileceğini; zamanla ortaya çıkan başta Haskala ve sonrasında Liberalizm, Sosyalizm ve Siyonizm gibi akımların etkisiyle sahip olduğu tüm dini ve kültürel değerlerini koruma güdüsüyle hareket ederek her türlü modern yaşamın ve toplumların dayattığı değiş̧im isteklerine karşı durarak bugünkü dünyada sanki başka bir âlemden gelmişler ve başka bir dünyada yaşıyorlar izlenimi veren bir hareket olduğu ifade edebiliriz.

Hasidizm Yahudi mistik geleneğinde daha önce var olan, ancak tamamen özel çevreler tarafından icra edilen Zohar'cı ve Lurianik Kabala'nın kavram ve teolojisini kullanmakla birlikte geleneksel Yahudiliğin bu konudaki sınırlayıcı kurallarını dikkate almayarak Kabala pratiklerini dindarlığın önemli bir parçası haline getirmiş, böylece Kabala'nın uygulama sahasını genişletmiştir. Kabala mesihçiliğinin

Berger, The Pious Ones, 379-381.

83 Sharot, "Has. in Modern Society", 513, 517-518. 
eskatolojik yönüne önem veren Sabatay Sevi ve Jacob Frank hareketlerinden farklı olarak tsadik önderliğinde bireysel kurtuluşu ön plana çıkartmıştır.

Hasidik hareket ortaya çıkışı itibarıyla Hıristiyanlıktaki reform süreci ve Protestanlığın doğuşunu çağrıştırır tarzda geleneksel dindarlık anlayışına muhalefet ederek yüzlerce yıldır son derece önemli görülen pek çok hususu ikinci plana atmaları ve yerine yeni bazı uygulamalar koymaları biçiminde bir profil çizmesine rağmen, tarihsel süreç içerisinde yaşanan siyasi, sosyal, dini pek çok gelişmenin sonucunda Protestanlığın çizdiği profilden farklı olarak geleneksel değerlerin yılmaz savunucusu haline gelmiştir. Protestanlıkta olduğu gibi inancı ön plana çıkarmak suretiyle geleneksel Tevrat öğretimine mesafeli durmuş; tsadik ismi verilen yeni bir otorite ortaya koyması yönüyle geleneksel dini organizasyonu kökünden sarsmış; ibadetlerin amacının vecd haline ulaşmak olduğunu ifade ederek hem geleneksel Rabbâni hem de Kabalacı din anlayışına karşı dini bir yenilik yapmıştır.

Kurduğu organize toplumsal yapısı, başta eğitim ve sağlık olmak üzere diğer gerekli sistemleri, cemaat içi yazılı olmayan normları ve geleneksel değerlerini korumaya yönelik muhafazakâr tutumları ile modern toplumlar içerisinde münzevi bir yaşam tarzı seçmeden varlıklarını devam ettirebilmeleri sebebiyle sosyolojik, psikolojik, etnolojik açılardan dikkatle incelenmeleri gereken nev-i şahsına münhasır bir gruptur.

Hasidik cemaatlerin güçlü grup içi dayanışmaları vardır. Okul sistemleri ile genç kuşaklara kendi değerlerini aktarabilmektedir. Grup içi evlilik ve yüksek doğum oranları ile sayılarının hızla artmaktadır. Üyeleri büyük oranda dış dünyanın gerektirdiği eğitim, bilgi, birikim ve donanımdan yoksun olması sebebiyle gruptan ayrılmaya cesaret edememektedir. İnternet gibi modern hayatın temel enstrümanlarından olabildiğince uzak durmaktadırlar. Zorunlu ekonomik bağlantılar haricinde yabancılarla iletişim halinde olmayı yasaklayan sıkı kuralları vardır. Topluluklarının manevi saflığına inandıklarından bu saflığı korumak için oluşturulmuş olan kendi iç denetim mekanizmaları yoluyla mevcut düzenlerini sürdürebilmektedirler. Bu süreçte grup üyelerinin dış dünyadan izolasyonu ve sosyal kontrolü son derece ehemmiyet arz etmektedir. Bunu sağlamak için özellikle kılık kıyafet konusunda geleneklerine sıkı sıkıya bağlı kalmak ve ibadette İbranice, konuşma dili olarak -çoğunlukla- Yiddiş dilini kullanmak suretiyle farklı kalmayı ve izolasyonu (ve kontrolü) sağlamaktadırlar. Günümüzde Yahudiliğin en hızlı büyüyen grubunu teşkil eden Hasidik hareketin modern Yahudilik için sağladığı en önemli katkılardan birisi zengin folklor, efsane ve kıssa literatürünü bugüne taşımasıdır. 


\section{Kaynakça}

Altshuler, Mor. The Messianic Secret of Hasidism. Leiden\&Boston: Brill, 2006.

Arslantaş, Nuh. "Abbasiler Döneminde Yahudilerin Temel Eğitim Kurumları: Bet ha-Seferler ve Beytülmidraslar". Belleten LXXVIII/282 (Ağustos 2014): 435-474.

Assaf, David. "Hasidism, Historical Overview". The Yivo Encyclopedia of Jews in Eastern Europe. 1: 659-670. New Haven (Conn.): Yale Univ. Press, 2008.

Belcove-Shalin, Janet S. "Home in Exile: Hasidism in the New World". New World Hasidim: Ethnographic Studies of Hasidic Jews in America. Ed. Janet S. Belcove-Shalin. USA: State Univ. of New York Press, 1995.

Berger, Joseph. The Pious Ones: The World of Hasidim and Their Battles with America. New York: Harper Perennial, 2014.

Biale, David - Assaf, David - Brown, Benjamin. Hasidism: A New History. USA: New Jersey: Princeton Univ. Press, 2018.

Buber, Martin. Hasidism and Modern Man. Trc. Maurice Friedman. New York: Harper Torchbook, 1966.

Buber, Martin. The Origin and Meaning of Hasidism. Trc. Maurice Friedman. New Jersey: Humanities Press, 1993.

Caravella, Miriam B. The Mystic Heart of Judaism. New Delhi: Science of the Soul Research Centre, 2011.

Dan, Joseph. "Hasidism". Encyclopaedia of Religion. USA: Macmillan Reference USA, 2005.

Demirci, Kürșat. “Doğu Avrupa Yahudiliği: Hasidizm”. Din Eğitimi Araștırmaları Dergisi. 16 (2005): 119-128.

Demirci, Kürşat. Yahudi Mistisizmi veya Kabalacıllk. İstanbul: Ayışı̆̆g Kitapları, 2015.

Demirci, Kürşat. "Yahudi Mistisizminin Temel Özellikleri ve Gelişimi". İnsan ve Toplum Bilimleri Araştırmaları Dergisi 4 (2012): 7-18.

Elior, Rachel. The Mystical Origins of Hasidism. Oxford: The Littman Library of Jewish Civilization, 2008.

Etkes, Immanuel. The Besht: Magician Mystic and Leader. Trc. Saadya Sternberg. USA: Massachusetts: Brandeis University Press, 2005.

Ettinger, Shmuel. "The Hasidic Movement-Reality and Ideals". Essential Papers on Hasidism. Ed. Gershon David Hundert. New York and London: New York Univ. Press, 1991.

Flatto, Sharon. "Hasidim and Mitnaggedim: Not a World Apart". The Journal of Jewish Thought and Philosophy 12/2 (August 2003): 99-121.

Frigyesi, Judith. "Music: Music for Sacred Texts". The Yivo Encyclopedia of Jews in Eastern Europe. Yivo Institute for Jewish Research. Erișim 28 Șubat 2020. https://yivoencyclopedia.org/article.aspx/Music/Music_for_Sacred_Texts.

Gartner, Lloyd P. “Hasidism, United States ('Hasidism' içinde)”. Encyclopaedia Judaica. 8/397. USA: Macmillan Reference USA, 2007.

Ginzberg, Louis. Students Scholars and Saints. New York: Meridian Books and Jewish Pub. Society, 1958.

Green, Arthur. "Piety". The Yivo Encyclopedia ofJews in Eastern Europe. Yivo Institute for Jewish Research. Erişim 03 Şubat 2020. https://yivoencyclopedia.org/article.aspx/Piety.

Idel, Moshe. Hasidism Between Ecstacy and Magic. New York: State Univ. of New York Press, 1995.

Jacobs, Joseph - Eisenstein, Judah David. "Sippurim”. The Jewish Encyclopaedia. 11/386-388. New York and London: Funk and Wagnalls Company, 1905.

Jacobs, Joseph - Cohen, Francis L. "Zemirot". The Jewish Encyclopaedia. 12/656-660. New York 
and London: Funk and Wagnalls Company, 1906.

Jacobs, Louis. “Basic Ideas of Hasidism ('Hasidism' içinde)”. Encyclopaedia Judaica. 8/407-410. USA: Macmillan Reference USA, 2007.

Jacobs, Louis. "Hasidism: Everyday Life". The Yivo Encyclopedia of Jews in Eastern Europe. Yivo Institute for Jewish Research. Erişim 28 Şubat 2020. https://yivoencyclopedia.org/article.aspx/Hasidism/Everyday_Life.

Katz, Dovid. "Yiddish Language". The Yivo Encyclopedia of Jews in Eastern Europe. Erişim 02 Şubat 2020. https://yivoencyclopedia.org/article.aspx/Language/Yiddish.

Kitab-ı Mukaddes. İstanbul: Kitabı Mukaddes Şirketi, 1997.

Klier, John. "Pogroms". The Yivo Encyclopedia of Jews in Eastern Europe. Yivo Institute for $\begin{array}{lllll}\text { Jewish } & \text { Research. } & \text { Erişim } & 02020\end{array}$ https://yivoencyclopedia.org/article.aspx/Pogroms.

Kohler, Kaufmann - Ginzberg, Louis. "Ba'al Shem Tob, Israel ben Eliezer". The Jewish Encyclopaedia. USA: Funk and Wagnalls Company, 1903.

Koskoff, Ellen. "Language of the Heart: Music in Lubavitcher Life". New World Hasidim. Ed. Janet S. Belcove-Shalin. 87-106. USA: State Univ. of New York Press, 1995.

Kurt, Ali Osman. Fundamentalist Yahudiler. Ankara: Eskiyeni Yayınları, 2016.

Kurt, Ali Osman. "Yahudi Aydınlanma Hareketi: Haskala". Milel ve Nihal 7/1 (2010): 33-59.

Leifert, R. Aryeh. "The Role of Messianism in the Development of Hasidism". Milin Havivin. 2 (2006). https://library.yctorah.org/files/2016/09/The-Role-of-Messianism-in-theDevelopment-of-Hasidism.pdf.

Magid, Shaul. Hasidism on the Margin. Madison: The University of Wisconsin, 2003.

Mahler, Raphael. "Hasidism and the Jewish Enlightenment". Essential Papers on Hasidism. New York and London: New York Univ. Press, 1991.

Martin, Bernard. A History of Judaism : Europe and the New World. 2 Cilt. New York: Basic Books, 1974.

Mazor, Yaakov. "Hasidism: Dance". The Yivo Encyclopedia of Jews in Eastern Europe. Yivo Institute for Jewish Research. Erişim 26 Şubat 2020. https://yivoencyclopedia.org/article.aspx/Hasidism/Dance.

Metli, Ebru. Hasidizm'in Yahudi ve Öteki Anlayışı. Yüksek Lisans Tezi, Ankara Üniversitesi, 2006.

Monet, E. "Hasideans, Hasidism". Encyclopaedia of Religion and Ethics. Ed. James Hasting. 6/916. Edinburg: T.\&T. Clark, 1919.

Petrovsky-Shtern, Yohanan. "Ba'ale Shem". The Yivo Encyclopedia of Jews in Eastern Europe. Yivo Institute for Jewish Research. Erişim 02 Şubat 2020. https://yivoencyclopedia.org/article.aspx/Baale_Shem.

Poll, Solomon. "The Charismatic Leader o f the Hasidic Community: The Zaddiq, the Rebbe". New World Hasidim. Ed. Janet S. Belcove-Shalin. 257-275. USA: State Univ. of New York Press, 1995.

Rabinowicz, Harry M. The World of Hasidism. London: Vallentine, Mitchel, 1970.

Ravitzky, Aviezer. "The Contemporary Lubavitch Hasidic Movement: Between Conservatism and Messianism". Accounting for Fundamentalisms: The Dynamic Character of Movements. Ed. Martin E. Marty - R. Scott Appleby. 303-327. Chicago and London: The Univ. of Chicago Press, 1994.

Rosenthal, Herman - Dubnow, S. M. "Hasidim, Hasidism". The Jewish Encyclopaedia. 6/251256. New York and London: Funk and Wagnalls Company, 1904.

Rosman, Moshe. "The Rise of Hasidism". The Cambridge History of Judaism: The Early Modern 
World, 1500-1815. Ed. Jonathan Karp - Adam Sutcliffe. 7/1136. Cambridge: The Cambridge Univ. Press, 2018.

Rubinstein, Avraham. "Hasidism". Encyclopaedia Judaica. 8/393-434. USA: Macmillan Reference USA, 2007.

Schlossberg, Eli W. The World of Orthodox Judaism. New Jersey\&London: Jason Aronson Inc., 1986.

Scholem, Gershom. The Messianic Idea in Judaism. New York: Schocken Books, 1971.

Scholem, Gershom G. Major Trends in Jewish Mysticism. 8. bs. New York: Schocken Books, 1974.

Sharot, Stephen. "Hasidism in Modern Society". Essential Papers on Hasidism. New York and London: New York Univ. Press, 1991.

Shatz-Uffenheimer, Rivka. “Teachings of Hasidim ('Hasidim' içinde)”. Encyclopaedia Judaica. 8/410-417. USA: Macmillan Reference USA, 2007.

Van Loenen, Eva. "A Fresh Perspective on the History of Hasidic Judaism". eSharp. 20 (Spring 2013): 1-23.

Wertheimer, Jack. "Jews and the Jewish Birthrate", Erişim 28 Şubat 2021. https://www.aish.com/jw/s/48899452.html.

Wilensky, Mordecai L. "Hasidic-Mitnaggedic Polemics in the Jewish Communities of Eastern Europe: The Hostile Phase". Essential Papers on Hasidism. Ed. Hundert, Gershon David. New York and London: New York Univ. Press, 1991.

Wodzinski, Marcin. Hasidism and Politics: The Kingdom of Poland,1815-1864. Oxford: The Littman Library of Jewish Civilization, 2013.

Wodzinski, Marcin. Historical Atlas of Hasidism. Princeton, New Jersey: Princeton Univ. Press, 2018.

Wodzinski, Marcin - Garlinsky, Jarek. "War and Religion; or, How the First World War Changed Hasidism". The Jewish Quarterly Review 106/3 (Summer 2016) (t.y.): 283-312.

Zahavy, Tzvee. "Jewish Piety". The Blackwell Companion to Judaism. Ed. Jacob Neusner - Alan J. Avery-Peck. 553. Oxford: Blackwell Publishing, 2000. 